\title{
Archeological Testing Associated with theStabilization of the Convento at Mission San Juan Capistrano (41BX5), San Antonio, Bexar County, Texas
}

Karla J. Córdova

Antonia L. Figueroa

Center for Archeological Research, University of Texas at San Antonio

Kristi M. Ulrich

Johanna M. Hunziker

Follow this and additional works at: https://scholarworks.sfasu.edu/ita

Part of the American Material Culture Commons, Archaeological Anthropology Commons, Environmental Studies Commons, Other American Studies Commons, Other Arts and Humanities Commons, Other History of Art, Architecture, and Archaeology Commons, and the United States History Commons

Tell us how this article helped you.

This Article is brought to you for free and open access by the Center for Regional Heritage Research at SFA ScholarWorks. It has been accepted for inclusion in Index of Texas Archaeology: Open Access Gray Literature from the Lone Star State by an authorized editor of SFA ScholarWorks. For more information, please contact cdsscholarworks@sfasu.edu. 


\section{Archeological Testing Associated with theStabilization of the Convento at Mission San Juan Capistrano (41BX5), San Antonio, Bexar County, Texas}

\section{Creative Commons License}

\section{(c) (1) (8)}

This work is licensed under a Creative Commons Attribution-NonCommercial 4.0 International License 


\section{Archeological Testing Associated with the Stabilization of the Convento at Mission San Juan Capistrano (4 1BX5), San Antonio, Bexar County, Texas}

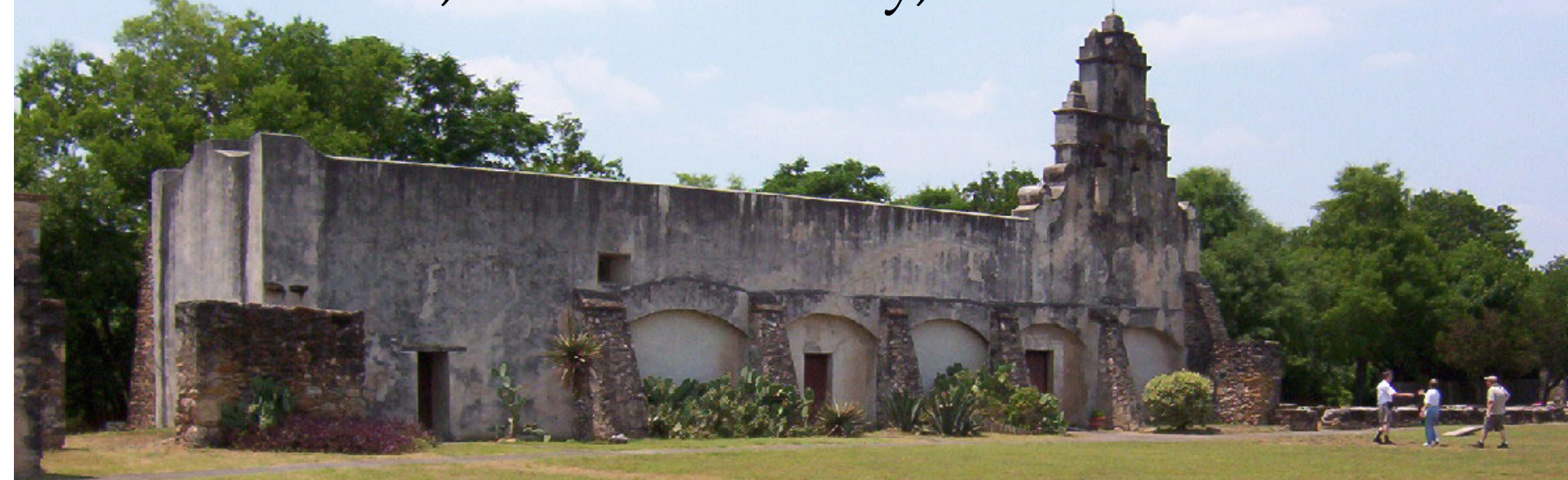

by

Karla J. Córdova, Antonia L. Figueroa, Kristi M. Ulrich, and Johanna M. Hunziker

Center for Archaeological Research

The University of Texas at San Antonio

Archaeological Report, No. 358

(C)2005 


\title{
Archeological Testing Associated with the Stabilization of the Convento at Mission San Juan Capistrano (41BX5), San Antonio, Bexar County, Texas
}

\author{
by \\ Karla J. Córdova, Antonia L. Figueroa, Kristi M. Ulrich, \\ and Johanna M. Hunziker
}

Texas Antiquities Committee Permit No. 3655

Principal Investigator

Steve A. Tomka

Prepared for:

National Park Service

San Antonio Missions National Historical Park

San Antonio, Texas
Prepared by:

Center for Archaeological Research The University of Texas at San Antonio Archaeological Report, No. 358 
Cover photograph of Mission San Juan Capistrano courtesy of Marybeth Tomka.

A list of publications offered by the Center for Archaeological Research is available. Call (210) 458-4378; write to the Center for Archaeological Research, The University of Texas at San Antonio, 6900 N. Loop 1604 W., San Antonio, Texas 78249-0658; e-mail to car@lonestar.utsa.edu; or visit CAR's web site at http://car.utsa.edu. 


\section{Abstract:}

In January and April, 2005, the Center for Archaeological Research (CAR) of The University of Texas at San Antonio conducted test excavations at Mission San Juan Capistrano (41BX5) for the San Antonio Missions National Historical Park of the National Park Service. The site is located approximately eight miles south of downtown San Antonio on the left bank of the San Antonio River.

The purpose of the excavations was to provide information on the nature and content of the subsurface deposits in preparation for a major stabilization campaign around the convento at Mission San Juan that will result in the installation of an impermeable barrier around the structure. Concrete footers will also be installed under each buttress, if necessary. Six 1-x-1-meter units were excavated around the convento and Rooms 19 and 21. Excavations conducted by CAR revealed disturbed deposits on the west side of the convento. A cut-stone step feature was encountered on the southeast side of the convento, along with a footer that was exposed near the northeast corner of the building. Excavations also revealed the original sandstone foundation of San Juan Capistrano on the south side of Room 21.

These investigations were conducted under Texas Antiquities Committee permit no. 3655 with Dr. Steve A. Tomka, CAR Director, serving as Principal Investigator. All cultural materials recovered and project-related documents are permanently curated at the Center for Archaeological Research. 


\section{Table of Contents:}

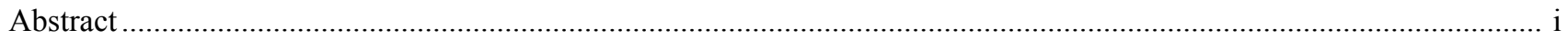

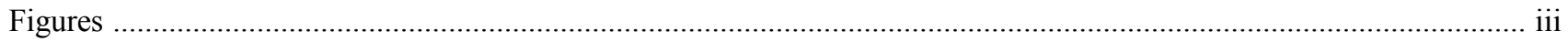

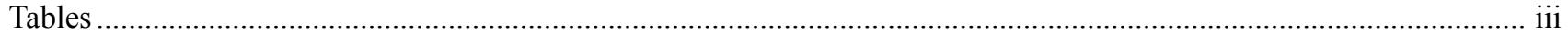

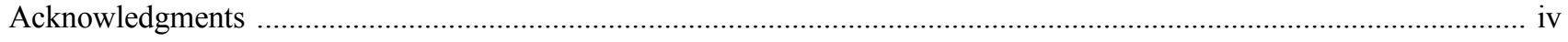

Chapter 1: Introduction

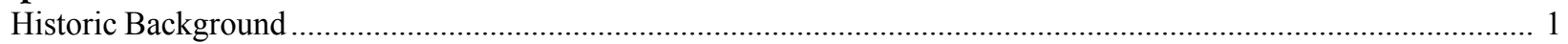

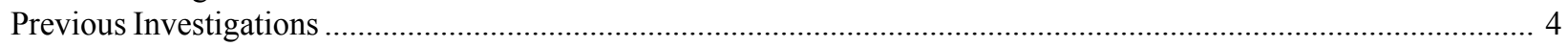

Chapter 2: Field Methodology and Laboratory Procedures

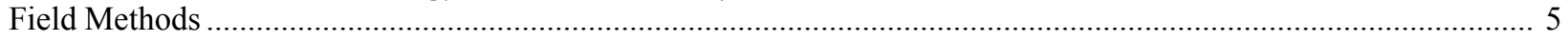

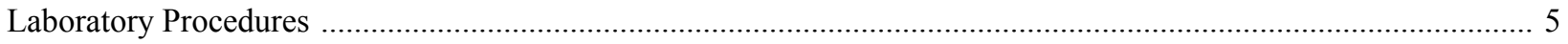

Chapter 3: Unit and Soil Descriptions

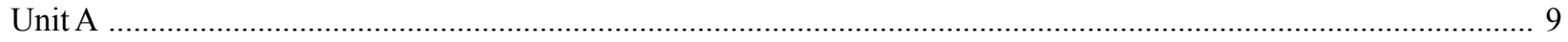

Unit B . . . . . . .

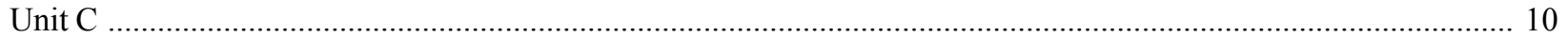

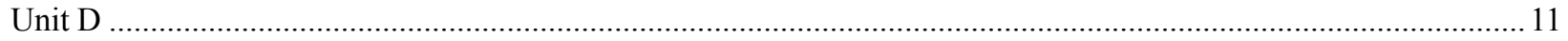

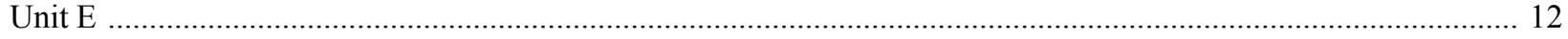

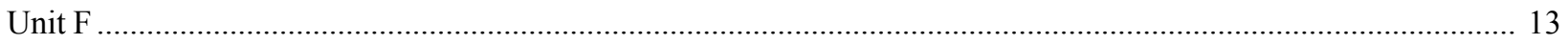

Chapter 4: Artifact Recovery

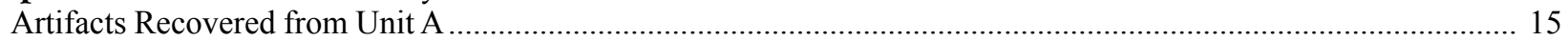

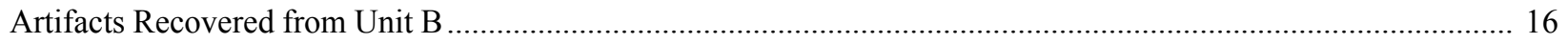

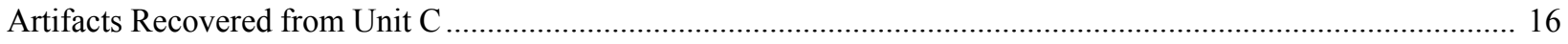

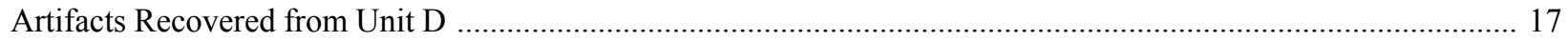

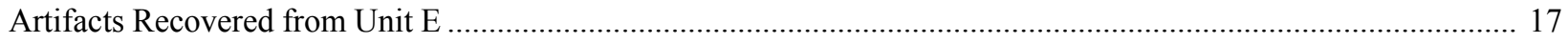

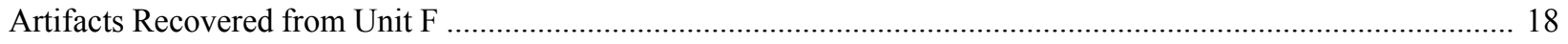

Chapter 5: Artifact Classification and Analysis

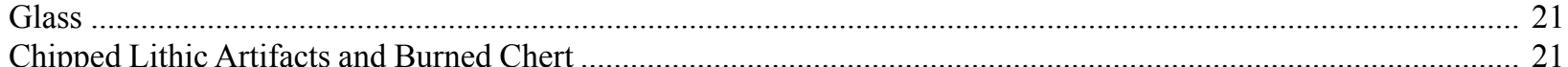

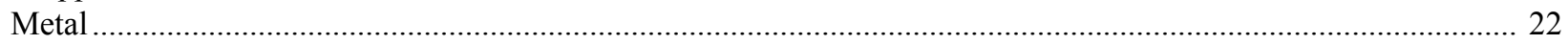

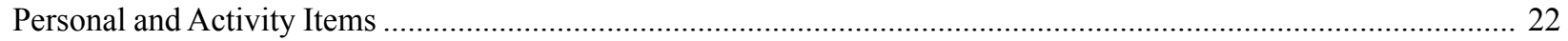

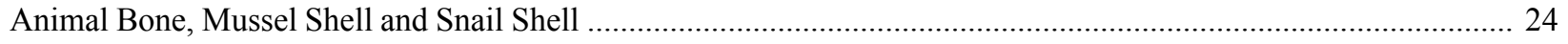

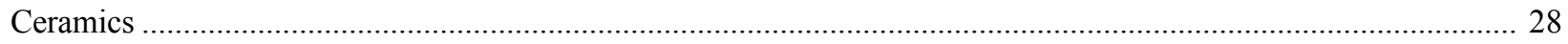

Chapter 6: Summary and Recommendations

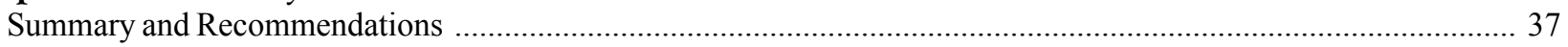

References Cited

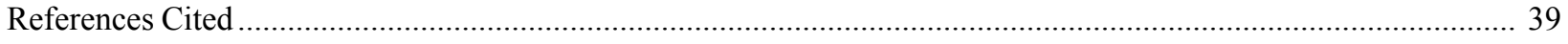

Appendix A

Recorded Analysis Attributes for Goliad Ceramics from Mission San Juan Capistrano ........................................... 43 


\section{Figures:}

Figure 1-1. Location of Mission San Juan Capistrano in Bexar County, Texas. ............................................................... 2

Figure 1-2. Map of Mission San Juan Capistrano with relevant rooms labeled. …….................................................... 3

Figure 2-1. The locations of Test Units A through F in the convento area at San Juan Capistrano. ................................... 6

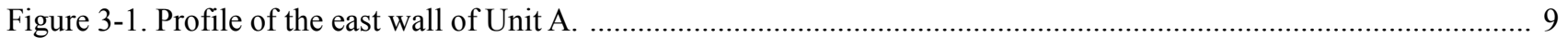

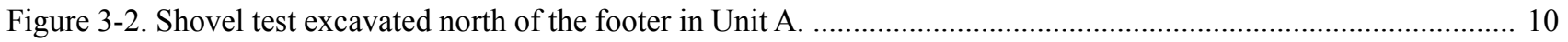

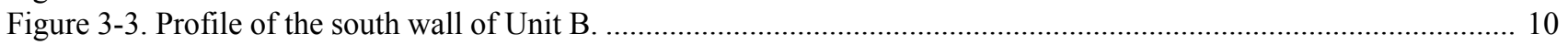

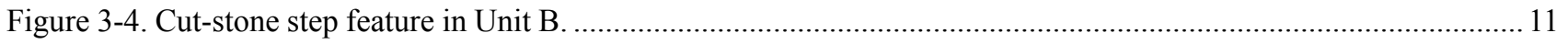

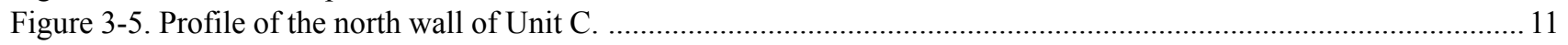

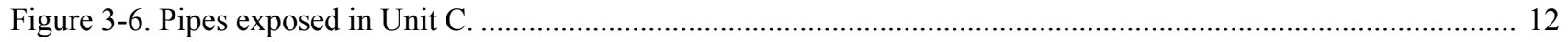

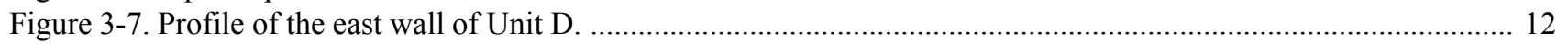

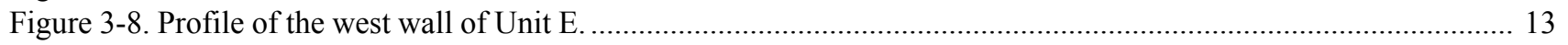

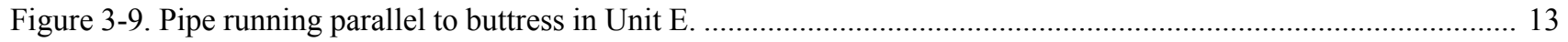

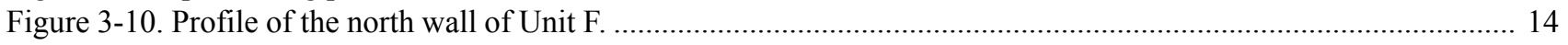

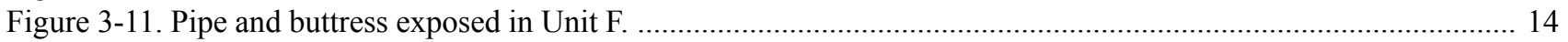

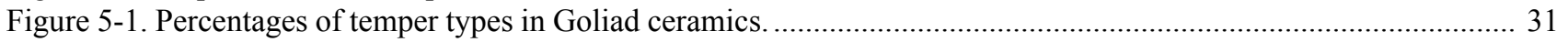

Figure 5-2. Percentages of temper material density in Goliad ceramics. ....................................................................... 32

Figure 5-3. The firing atmosphere of Goliad sherd cores, exteriors and interiors (percentages). ................................. 33

Figure 5-4. Finishing techniques of Goliad sherd interior and exterior surfaces (percentages). .................................... 34

Figure 5-5. Decoration of Goliad sherd interior and exterior surfaces (percentages). ................................................... 35

\section{Tables:}

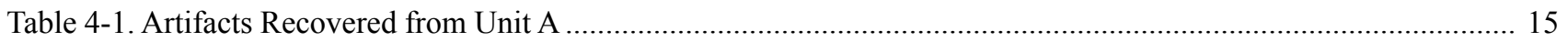

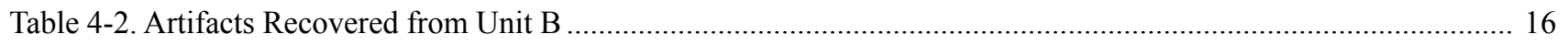

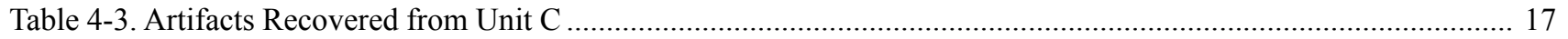

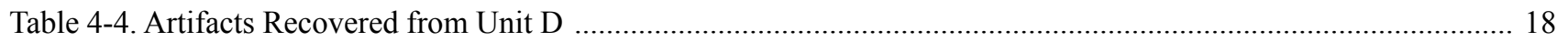

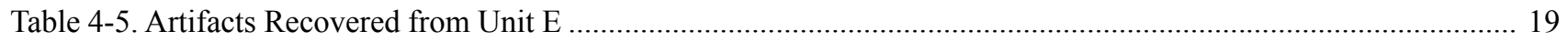

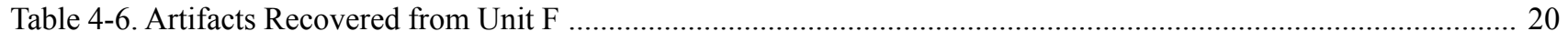

Table 5-1. Glass Recovered from Excavations ..................................................................................................... 21

Table 5-2. Chipped Stone and Burned Chert Recovered from Excavations ................................................................... 22

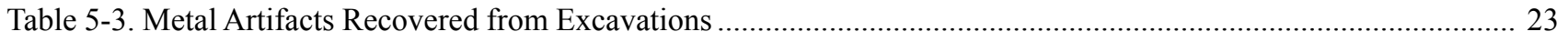

Table 5-4. Personal and Activity Items Recovered from Excavations .......................................................................... 23

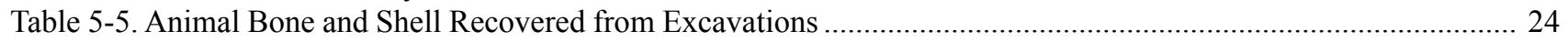

Table 5-6. Vertebrate Faunal Remains Recovered from Excavations ............................................................................. 25

Table 5-7. Counts, Weights and Percentages of Faunal Material Recovered from Units ................................................. 26

Table 5-8. Type and Frequency of Modifications to Vertebrate Remains ................................................................... 27

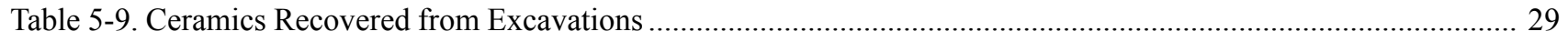

Table A-1. Analysis Attributes for Goliad Ceramics from Mission San Juan Capistrano .............................................. 44 


\section{Acknowledgments:}

The successful completion of this project would not have been possible without the assistance of a large number of people. We extend a special thanks to the National Park Service staff, especially archeologist Susan Snow, historical architect Michael Johnson, Park Ranger Daniel Cantu, and Thomas Castaños who so graciously helped at the mission and provided insightful information and assistance during the excavation. Well-deserved recognition goes to the field crew and lab technicians for their hard work in excavating and processing the materials obtained during the testing. They include the following individuals: Claudia Branton, Roman Clem, Lynn Eschenbaum, Antonia Figueroa, Bryant Saner, Marybeth Tomka and Kristi Ulrich. Thanks to Bruce Moses and Dr. Raymond Mauldin for the field mapping of the site and to Anne Fox for providing important information regarding previous work at the mission and valuable references. Bruce Moses and Rick Young produced the graphics for this report. Antonia Figueroa analyzed the Goliad ceramics and Johanna Hunziker identified the vertebrate faunal remains. Johanna Hunziker and Claudia Branton served as technical editors. Also, thanks to Dr. Steve Tomka, CAR Director, and Dr. Raymond Mauldin, CAR Assistant Director, for their guidance throughout all stages of this project. 


\section{Chapter 1: Introduction}

The Center for Archaeological Research (CAR) of The University of Texas at San Antonio was contracted by the National Park Service (NPS) to conduct test excavations at the Spanish Colonial convento in Mission San Juan Capistrano (41BX5), San Antonio, Bexar County, Texas (Figure 1-1). The site is listed on the National Register of Historic Places and is also a State Archeological Landmark. The archeological excavations were conducted in advance of a major stabilization campaign that will involve the installation of an impermeable barrier surrounding the convento. The impermeable barrier, consisting of a plastic polymer, will be installed at a depth of six inches in the immediate vicinity of the walls and will slope to 18 inches below surface by the time it extends out to eight feet from the base of the walls. The impermeable barrier will surround the convento building proper and also extend around the southwest corner of the compound along the western and southern walls of Rooms 19, 20, 21 and 22 (Figure 1-2). A concrete footer will be placed under each buttress, if deemed necessary. The objective of the archeological investigations was to identify whether any significant cultural deposits exist in the area to be impacted by the planned stabilization work. Specifically, the purpose of these investigations was to (1) identify any intact architectural features, and (2) examine the stratigraphy of the area to be impacted to determine the extent of the disturbances that have occurred over time around the convento.

The excavations were carried out in compliance with Section 106 of the National Historic Preservation Act (NHPA) of 1966 (as amended). The National Register of Historic Places (NRHP) and the Advisory Council for Historic Preservation were created by the NHPA and it is the stated role of the Advisory Council to comment when any potentially adverse actions are planned on properties listed on the NRHP. The Texas Historical Commission was the reviewing agency on behalf of the Advisory Council.

The field work was conducted during January and April, 2005 , and lasted a total of five work days. A crew ranging from two to six individuals carried out the fieldwork. Dr. Steve A. Tomka served as Principal Investigator and Karla J. Córdova was the project archeologist.

\section{Historic Background}

This section of the report presents a general overview of the historic background of Mission San Juan Capistrano. The reader is referred to Habig (1968), Ivey et al. (1990), Procter (1965), and Schuetz $(1968,1969,1974,1980)$ for a more detailed description of the development and history of this mission. A comprehensive overview of the archeological projects conducted at the mission is provided in Cox et al. (2001).

Mission San Juan Capistrano was originally founded in 1716 in East Texas under the name San José de los Nazonis (Habig 1968:13). The mission was abandoned and reoccupied several times prior to its final abandonment in 1729 , at which time Spanish attempts to establish missions in East Texas were suspended. In 1731, the mission was moved to its current location about eight miles south of downtown San Antonio on the left bank of the San Antonio River. It continued to be occupied throughout most of the nineteenth and early twentieth centuries. Originally, the mission was founded to serve the Orejone, Sayopine, Pamaque, and Piquiquie Indians (Habig 1968:13).

In 1756, an account by Father Francisco Javier Ortiz describes San Juan Capistrano as a prosperous mission consisting of a church, a convent, a granary, and jacales that were subsequently replaced with permanent quarters made of stone (Habig 1968:33-42). There was an enclosed convento in the southwest corner of the compound by the early 1760 s.

In general, the nineteenth century was one of land transfers and change during which repairs occurred, new structures were built, and others fell into disrepair. The mission was partially secularized in 1794 and fully secularized in 1823, when its administration was turned over to the local diocese (Habig 1968:180). By the late 1930s, all the mission walls and rooms are thought to have belonged to the Archdiocese of San Antonio. A number of repairs to the chapel were completed between 1907 and 1910 while additional repairs took place circa 1915. During the 1930s, the Works Progress Administration (WPA) performed extensive excavations at 


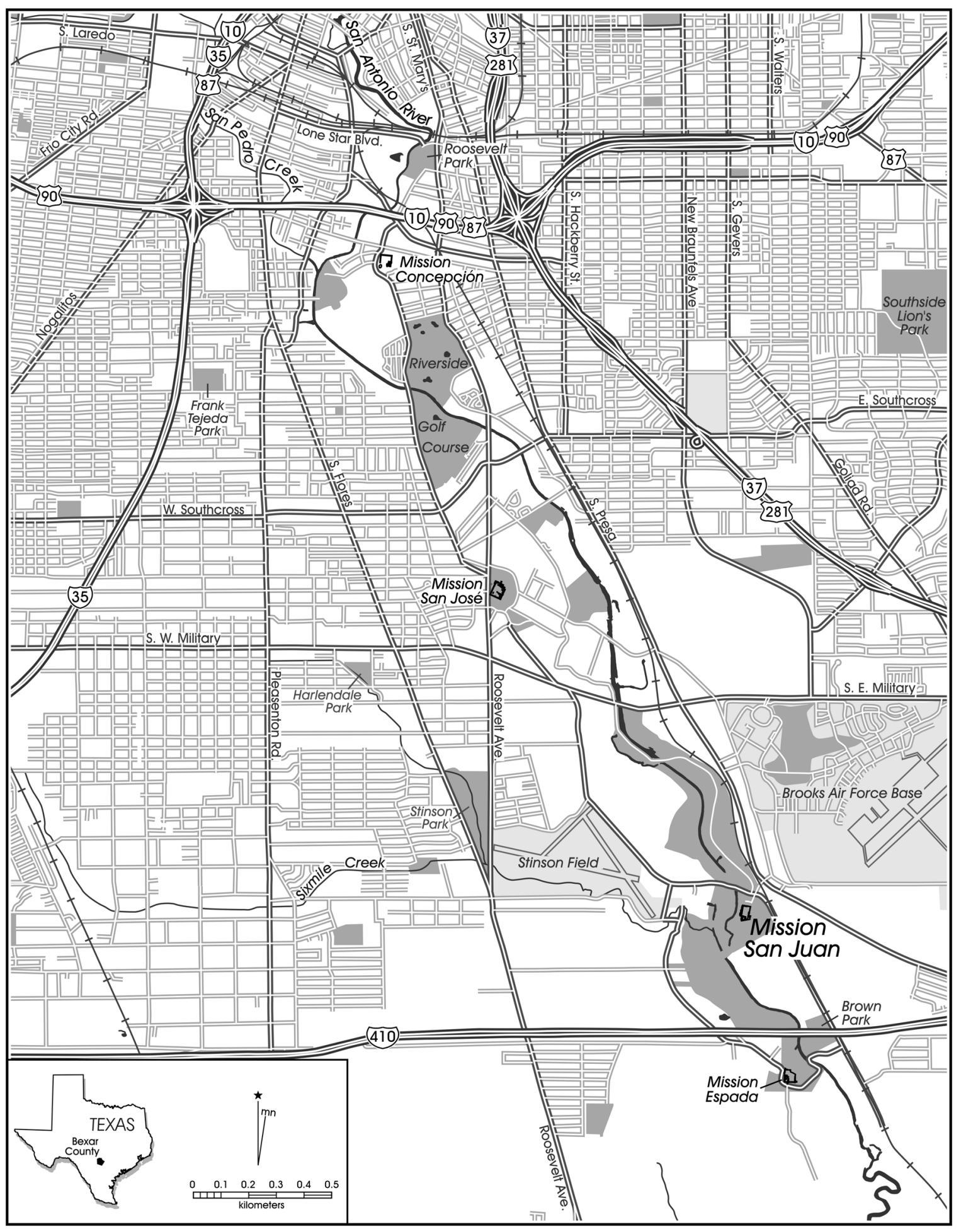

Figure 1-1. Location of Mission San Juan Capistrano in Bexar County, Texas. 


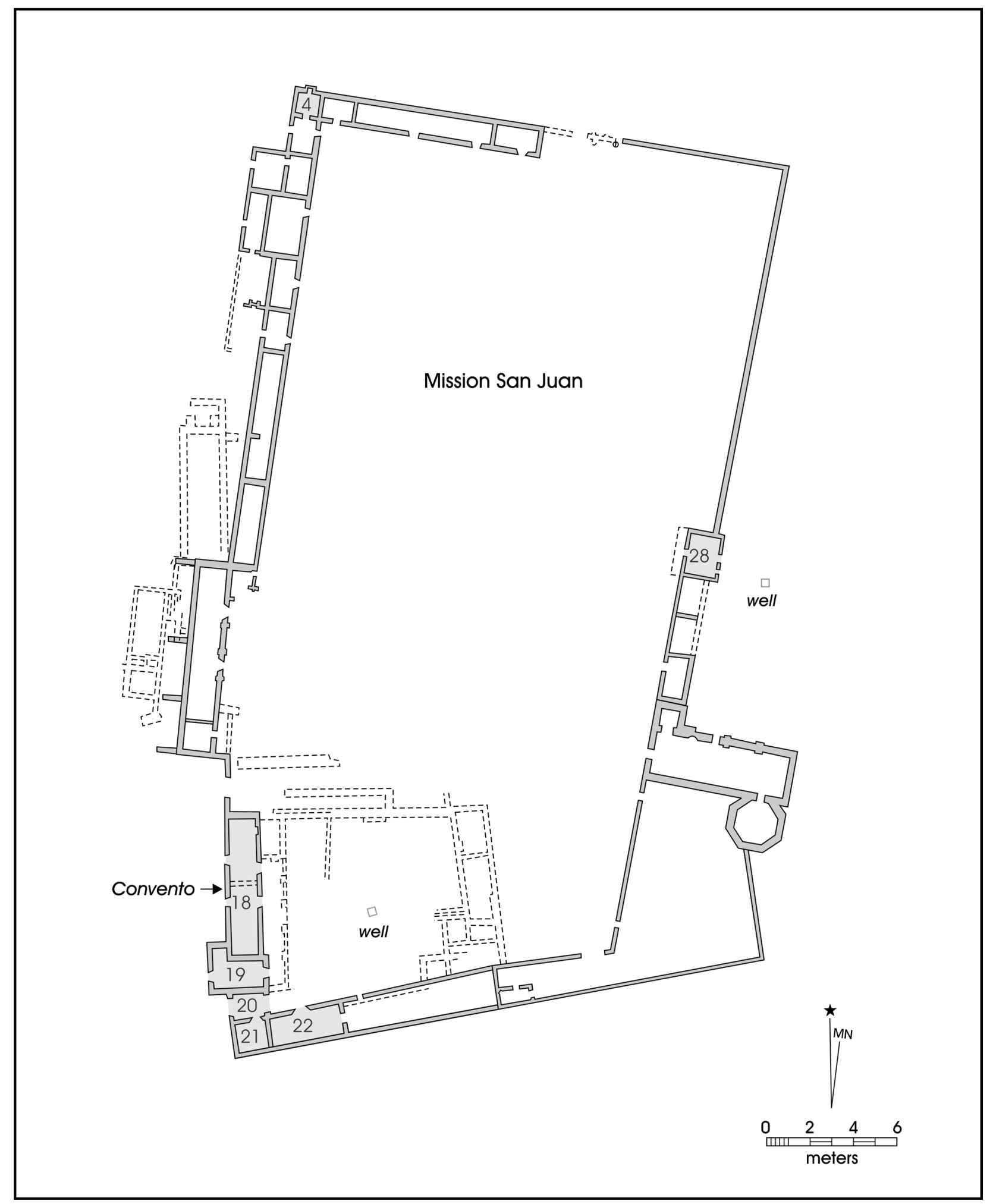

Figure 1-2. Map of Mission San Juan Capistrano with relevant rooms labeled. 
San Juan, exposing the buried foundations (Habig 1968:6568). The walls of the mission were partially restored in the 1950s (Gross 1998, Ivey et al. 1990). Likewise, some of the mission's rooms, walls, church, and parish hall were restored starting in the late 1960s (Gross 1998). Presently, Mission San Juan is part of the San Antonio Missions National Historical Park. The mission is jointly administered by the National Park Service and the Catholic Archdiocese of San Antonio.

\section{Previous Investigations}

A number of archeological investigations have taken place at Mission San Juan (41BX5) prior to the current project. In 1933, extensive WPA excavations were conducted at the mission under the direction of local architect Harvey P. Smith to relocate the wall foundations before restoration efforts were performed (Schuetz 1968, 1969). The first formal archeological investigations conducted at the mission were directed by Mardith Schuetz and Curtis Tunnell in 1967. These excavations investigated the northwest and southwest corners of the mission. They also identified the foundations of the incomplete church located on the east wall of the mission compound. In 1969, Schuetz returned to Mission San Juan to conduct test excavations beneath the floor of the present church before restoration work took place (Schuetz 1974). In 1971, Schuetz conducted additional excavations that focused on the area of the first convento located in the southwest part of the compound (Schuetz 1980). Subsequently, test excavations were conducted along the west side of the current church and the eastern façade of the chapel by Dan Scurlock in 1975 (Scurlock 1976). Between July and August, 1982, James Ivey conducted investigations at San Juan which focused on clarifying the construction sequence of the mission (Ivey and Fox 1999). A year later, James Escobar of NPS investigated the postColonial house, or Tufa House (Room 28), along the east wall of the compound (Escobedo 1985).

The most recent investigations conducted at Mission San Juan were carried out by CAR. A single excavation unit was completed by CAR in 1984 before stabilization of the chimney in Room 4 could take place (Fox 1999:10). In 1988, CAR archeologists tested the outside of the north wall and east of the gate prior to pipeline construction activities (Turner 1988:1). The 1988 excavations consisted of five 1-x-1-m units located north of the wall (Cox et al. 2001). Four separate areas near the eastern wall of the mission compound were tested by CAR in 1993 as part of a project aimed at alleviating drainage problems (Fox 1993). This project also included the monitoring of grading activities. In 1996, CAR archeologists performed shovel testing south of the mission for a proposed drainage channel (Gross 1998). In 1997, CAR undertook archeological investigations consisting of test unit excavations, shovel testing, and backhoe trenching for the National Park Service (Cargill and Robinson 2000). The most recent archeological investigations at the mission resulted from proposed trenching activities for the placement of underground utility lines in 1998. These investigations were performed by CAR and consisted of the excavation of four units located west of the current chapel and an additional unit located west of the priest's quarters (Cox et al. 2001:1). 


\section{Chapter 2: Field Methodology and Laboratory Procedures}

\section{Field Methods}

The scope of work that guided the archeological investigations conducted for this project was provided by the National Park Service (NPS) and included archeological testing, the preparation of the collection for curation, its entry into an $\mathrm{ANC}+$ (Automated National Catalog) database, and the preparation of a technical report detailing the results of the investigations and providing recommendations about the proposed stabilization impacts. According to NPS plans discussed with Susan Snow, NPS archeologist, a major stabilization campaign will be taking place in the convento area at Mission San Juan Capistrano. The stabilization campaign involves the installation of an impermeable plastic polymer barrier around the perimeter of the convento. The plastic sheeting is to be installed at a depth of six inches below surface in the vicinity of the walls and slope to 18 inches below surface at eight feet out from the bases of the wall. The barrier will surround the convento building and also extend along the southwestern corner of the compound. In addition, dependent on the structural integrity and stability of the buttresses, concrete footers may be installed under the buttresses, if needed.

To investigate the effects of these activities in the convento area and its vicinity, NPS required the excavation of five $1-x-1-m$ test units. Three of the test units were to be positioned against the bases of the east, north, and west walls of the convento while the fourth was to be situated against the outside wall of Rooms 21 and 22. The units were to be excavated to a depth of $60 \mathrm{~cm}$ in three arbitrary 20 -cm levels. An additional unit was to be located next to one of the buttresses along the west side of the convento. It was to be excavated to the base of the buttress in arbitrary $20-\mathrm{cm}$ levels. The depth of the base of the buttress was not known prior to excavation.

The initial fieldwork associated with the project was carried out in January, 2005. During the four days of work, six units were excavated around the convento (Figure 2-1). Four of the units (Units A, B, C, and D) were excavated to a depth of $60 \mathrm{~cm}$ in arbitrary $20-\mathrm{cm}$ levels. These units were placed to reveal the nature of the deposits in areas that would be impacted by the installation of the impermeable barrier. The fifth unit (Unit E), excavated against the base of one of the western buttresses of the convento, was excavated to a depth of $77 \mathrm{~cm}$. Excavations ceased before finding the bottom of the buttress because a 10-inch pipe was found in the middle of the unit running east-west from the convento building. Following consultation with Susan Snow, excavations in this unit were terminated and another test unit (Unit F) was laid out and excavated on the west side of the buttress. This additional unit was excavated to a depth of $120 \mathrm{~cm}$ in arbitrary $20-\mathrm{cm}$ levels exposing the bottom of the buttress at $110 \mathrm{~cm}$ below the surface.

All soil removed from the test units was screened through 1/4-inch mesh. Standard CAR Unit/Level forms were completed by the crew for each level of each unit, and a daily journal detailing progress of the excavations was completed by the project archeologist. Soil descriptions were completed for each level of each unit, to establish and document the characteristics of the deposits. Plan views and profiles were also drawn for each unit and photographs were taken when determined necessary. The locations of all units, as well as any disturbances encountered, were mapped using a Total Data Station. All cultural material recovered from the units was bagged with the appropriate provenience information and returned to the laboratory facilities at CAR.

In late April, the CAR crew was asked to return to carry out limited additional exploratory investigations to determine the depth of two architectural features encountered during the January work. These investigations were carried out on April 25, when the crew removed the balk between Unit B and the eastern wall of the convento to investigate the nature of two cut-stone blocks found in the unit in January.

\section{Laboratory Procedures}

All cultural materials and records obtained and generated during the project were prepared in accordance with federal regulation 36 CFR part 79, and Texas Historical Commission requirements for State Held-in-Trust collections. Artifacts processed in the CAR laboratory were washed, air-dried, and stored in 4-mil zip-locking archival-quality bags. Acidfree labels were placed in all artifact bags. Each label contains provenience information and a corresponding lot number laser-printed or written in pencil. Individual categories were then analyzed by specific attributes designated for each group. All data was entered into an 


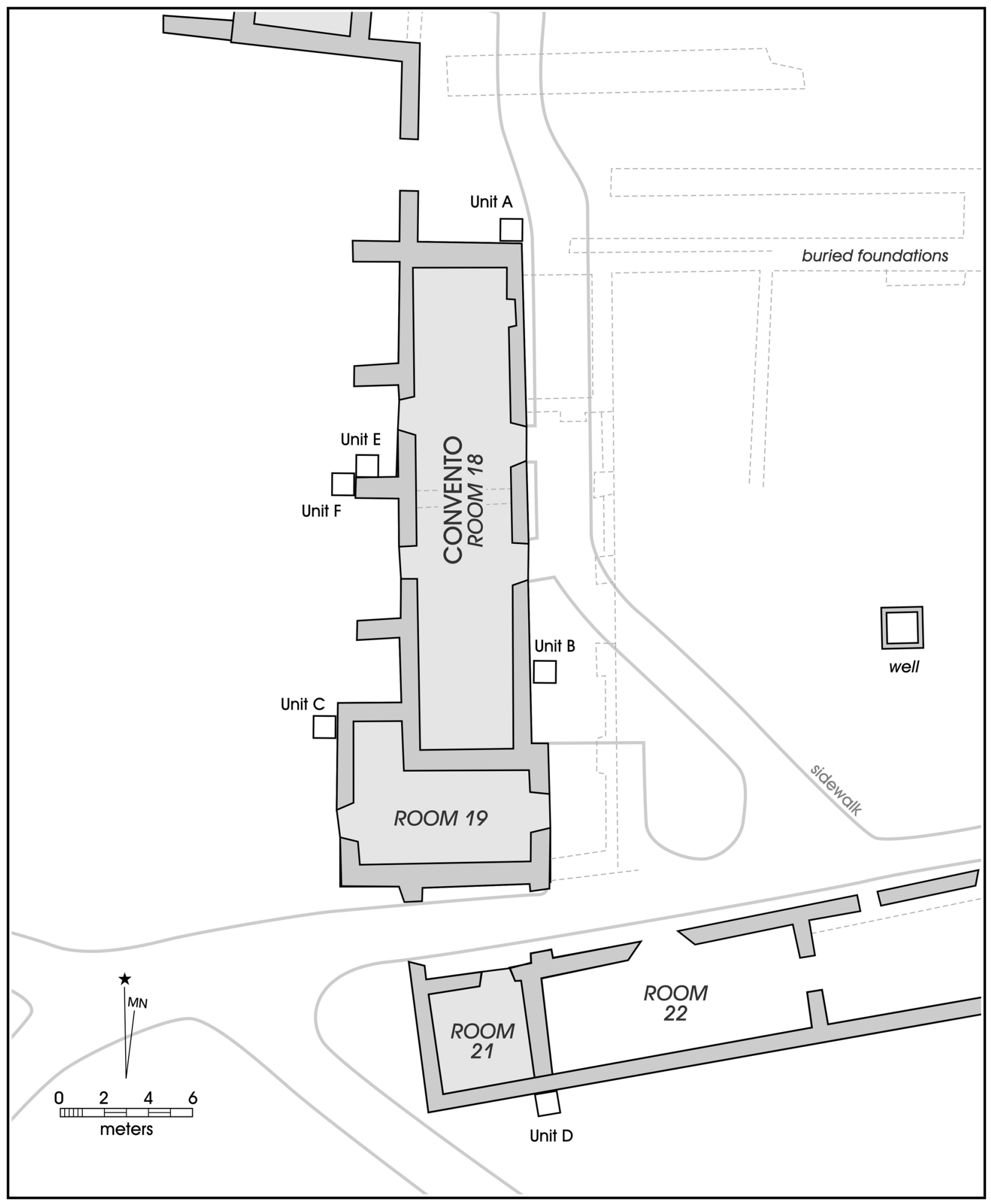

Figure 2-1. The locations of Test Units A through F around the convento area at Mission San Juan Capistrano. 
Excel spreadsheet. In addition, all artifact information was entered into the National Park Service ANC+ worksheets and database.

Following analysis, artifacts were separated by class and stored in acid-free boxes identified with standard tags. Field notes, forms, photographs, and drawings were placed in labeled archival folders. Photographs, slides, and negatives were labeled with archivally appropriate materials and placed in archival-quality sleeves. All field forms were completed with pencil. Documents and forms were printed on acid-free paper and any soiled forms were placed in archival-quality page protectors. Maps and illustrations produced by ink-jet printers also were placed in archivalquality page protectors. A copy of the testing report and all computer disks pertaining to the investigations were curated with the field notes and documents.

All artifacts and documentation pertaining to the project are permanently curated at the Center for Archaeological Research. 



\section{Chapter 3: Unit and Soil Descriptions}

\section{Unit A}

Unit A was located at the northeast corner of the convento (see Figure 2-1). The excavation revealed five stratigraphic zones within the unit (Figure 3-1). The first zone was a dark grayish brown (10YR 4/2) compact silty loam. The zone had a high gravel content and root inclusions were common throughout. The second zone was a very pale brown (10YR $7 / 4$ ) silty clay. This zone also contained a high concentration of gravel. The gravel concentration in these two zones ranged from $30 \%$ to $40 \%$. The third zone was a red clay lens $(2.5 \mathrm{YR}$ $4 / 8)$. A very dark gray (10YR 3/1) clay layer formed Zone IV. The bottom boundary of this zone was very diffuse. The soil in Zone $\mathrm{V}$ was a grayish brown (10YR 5/2) silt loam to silty clay loam. Zones I through III and a portion of IV were excavated as Level 1 (0-20 $\mathrm{cm}$ below datum [cmbd]), while Level 2 consisted of Zones III, IV, and V. Level 3 (40-60 $\mathrm{cmbd}$ ) was entirely within Zone V. At the end of Level 3, a stone footer (foundation stone) was exposed along the south wall of the unit.

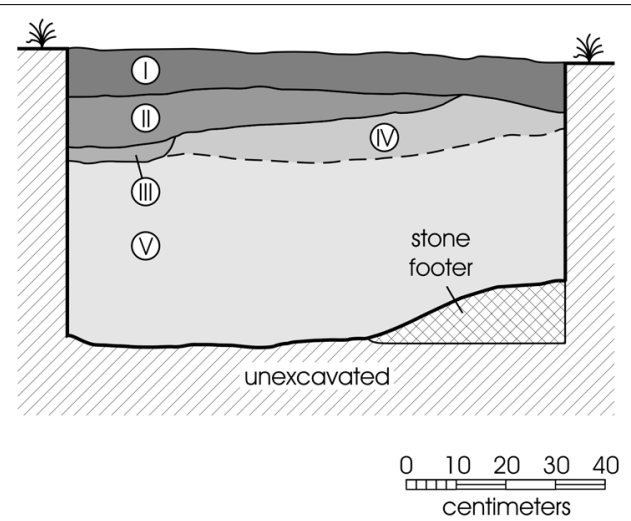

10YR4/2 dark grayish brown, compact silty loam, dry, rootlet inclusions, few gravels

(iI) 10YR7/4 very pale brown, dense gravel intrusion, little matrix, gravels are pea to $>5 \mathrm{~cm}$ in size, matrix dry

(III) $2.5 Y R 4 / 8$ red clay intrusion, matrix moist

(IV) 10YR3/1 very dark gray, clay cap intrusion, few grave inclusions, matrix moist

(v) 10YR5/2 grayish brown, silty loam to silty clay, gravel and rock inclusions, matrix moist
On April 25, 2005, the CAR crew returned to excavate an exploratory shovel test within Unit A to determine the depth of the footer (Figure 3-2). The shovel test measured approximately $50 \mathrm{~cm}$ in diameter. Level forms were not kept and the soil was not screened. Just below the footer, at about $90 \mathrm{cmbd}$, a course of stones was encountered that did not appear to be connected to the footer. The bottom of the stones was reached at $100 \mathrm{cmbd}(40 \mathrm{~cm}$ below the terminal depth of the initially excavated unit).

\section{Unit B}

Unit B was located along the east side of the convento (see Figure 2-1). This unit contained four stratigraphic zones. A cut-stone step feature was located along the west margin of the unit at 53-54 cmbd. It extended to the terminal depth of the unit, $60 \mathrm{cmbd}$ (Figure 3-3). Stratigraphic Zone I consisted of a dark gray (10YR 3/1) moist silty clay. The second stratigraphic zone was a brown (10YR 4/3) dry silty clay. The third zone encountered in Unit B was a thin lens of red $(2.5$ YR 4/8) clay that was not evident in the profile of the west wall. Zone IV consisted of a dark grayish brown (10YR $3 / 2)$ silty clay. Level $1(0-20 \mathrm{cmbd})$ contained Zones I and II, while Level $2(20-40 \mathrm{cmbd})$ consisted of Zones II, III and IV. The entirety of Level 3 (40-60 cmbd) consisted of Zone IV.

On April 25, 2005, the cut-stone feature in the western portion of Unit B was further exposed to the north and south (Figure 3-4). The feature consisted of two cut stones, reminiscent of the German masonry tradition (Susan Snow, personal communication 2005). The two cut stones were positioned atop a platform of flat sandstone pavers and limestone fragments to produce a level surface. Between the wall foundation and the stones, a roughly $12-\mathrm{cm}$ gap was filled with flat sandstone pavers cut and fit together. Several layers of the sandstone pavers were stacked to fill the gap. The seam between the two stones was filled with smaller fragments of the sandstone pavers. The two stones created a step $150 \mathrm{~cm}$ long and $20 \mathrm{~cm}$ high.

Figure 3-1. Profile of the east wall of Unit A. 


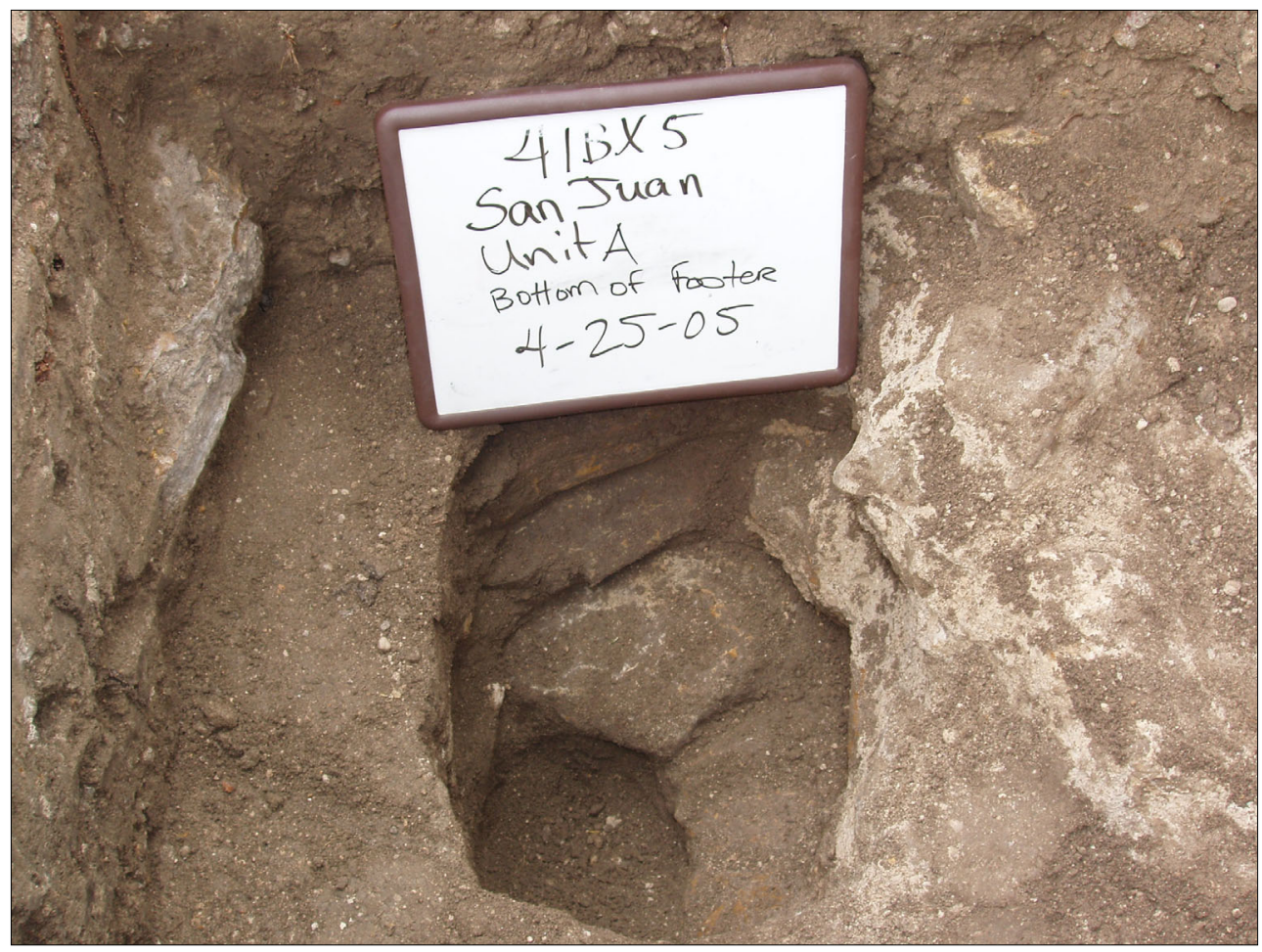

Figure 3-2. Shovel test excavated north of the footer in Unit A.

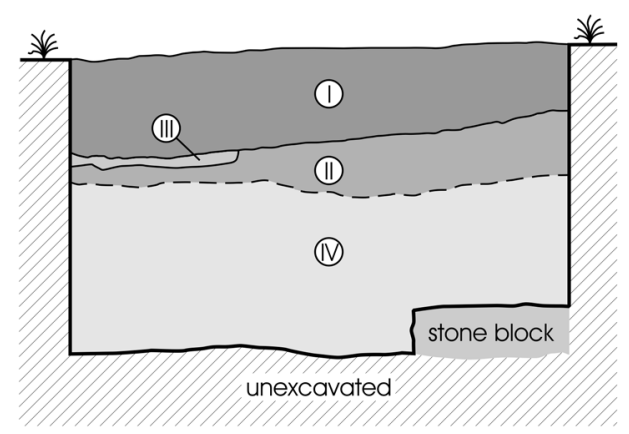

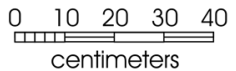

(1) 10YR3/1 very dark gray, compact, moist, silty clay

(II) 10YR4/3 brown, compact, dry, silty clay

(III) 2.5 YR $4 / 8$ red, intrusive silty clay/clay lens, few gravels

(IV) 10YR3/2 very dark grayish brown, slightly compact silty clay

\section{Unit C}

Unit C was located on the northwest side of Room 19 (see Figure 2-1). Six stratigraphic zones were identified in the unit. Zones I and II consisted of a gravel fill, while Zones III through VI ranged from gray to brown silts (Figure 3-5). Level 1 consisted of stratigraphic Zones I and II, while Level 2 contained Zones III and IV. Level 3 (40-60 cmbd) included depositional Zones V and VI. Two pipes were encountered in Level $2(20-40 \mathrm{cmbd})$. One was a 1 -inch gray PVC pipe found at $30 \mathrm{cmbd}$ (Figure 3-6). The second, a 2.5-inch gray PVC pipe, was encountered at $37 \mathrm{cmbd}$. Both pipes ran through the unit in an east-west direction and appeared to continue under the wall of Room 19. Directly under the pipes was a layer of ash in the easternmost half of the unit that was disturbed matrix from the pipe installation. Excavation of this unit was terminated at $60 \mathrm{cmbd}$.

Figure 3-3. Profile of the south wall of Unit B. 


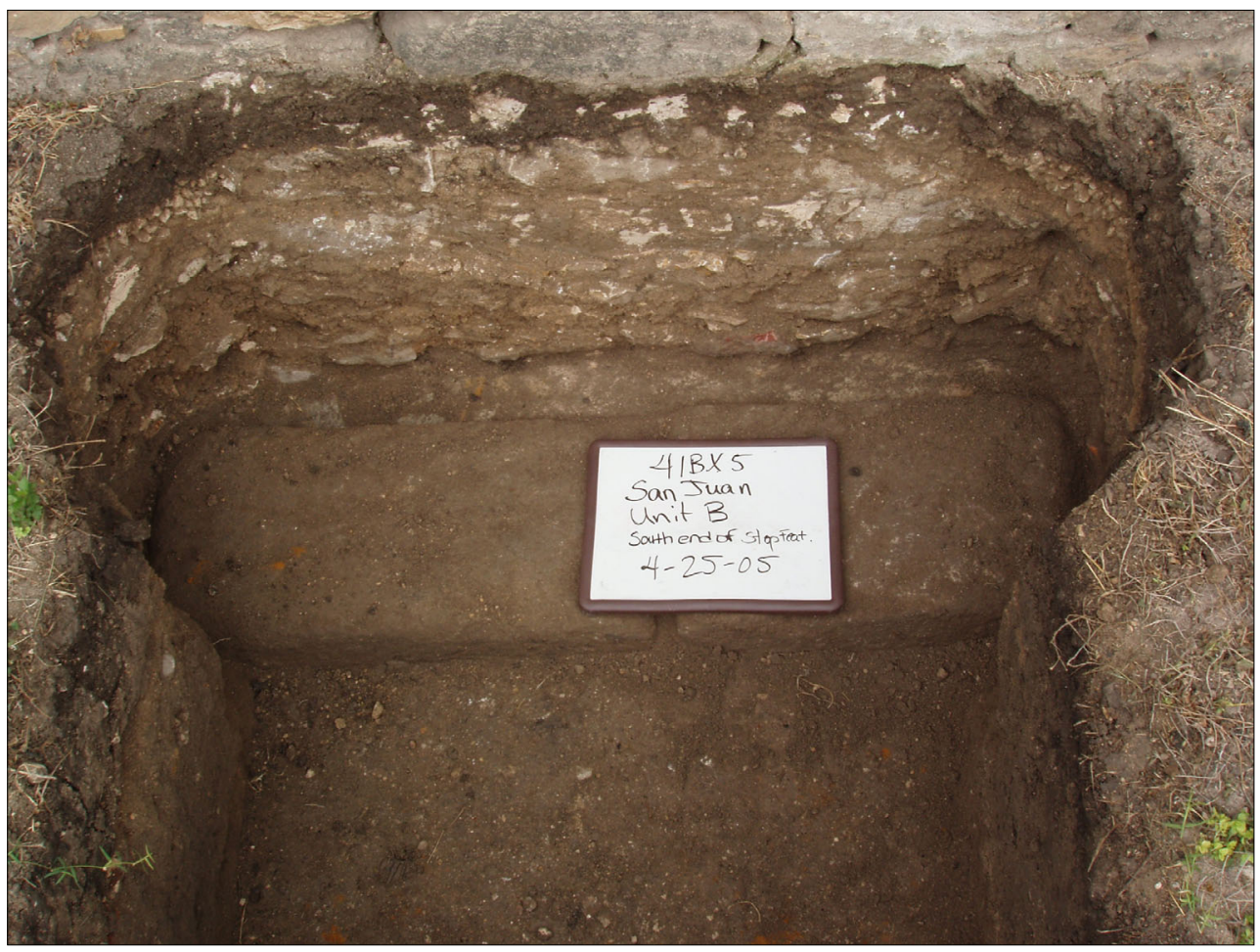

Figure 3-4. Cut-stone step feature in Unit B.

\section{Unit D}

Unit D was located on the south side of Room 21/Room 22 (see Figure 2-1). Four depositional/stratigraphic zones were defined in this unit. The first zone, contained within excavation Level $1(0-20 \mathrm{cmbd})$, was heavily disturbed (Figure 3-7). The grayish brown (10YR 5/2) fill contained numerous chunks of concrete and sandstone construction refuse. The sandstone foundation of the building was exposed along the north wall of the unit during excavation. The second zone, which spanned Level $2(20-40 \mathrm{cmbd})$ and extended into the top of Level $3(40-60 \mathrm{cmbd})$, continued to exhibit signs of disturbance, although the matrix became less disturbed toward the bottom of the zone. The matrix in this zone was comprised of brown silty soil with small gravel inclusions. Stratigraphic Zone III consisted of a silty brown matrix and was contained within Level 2 . The fourth stratigraphic zone included the majority of Level 3

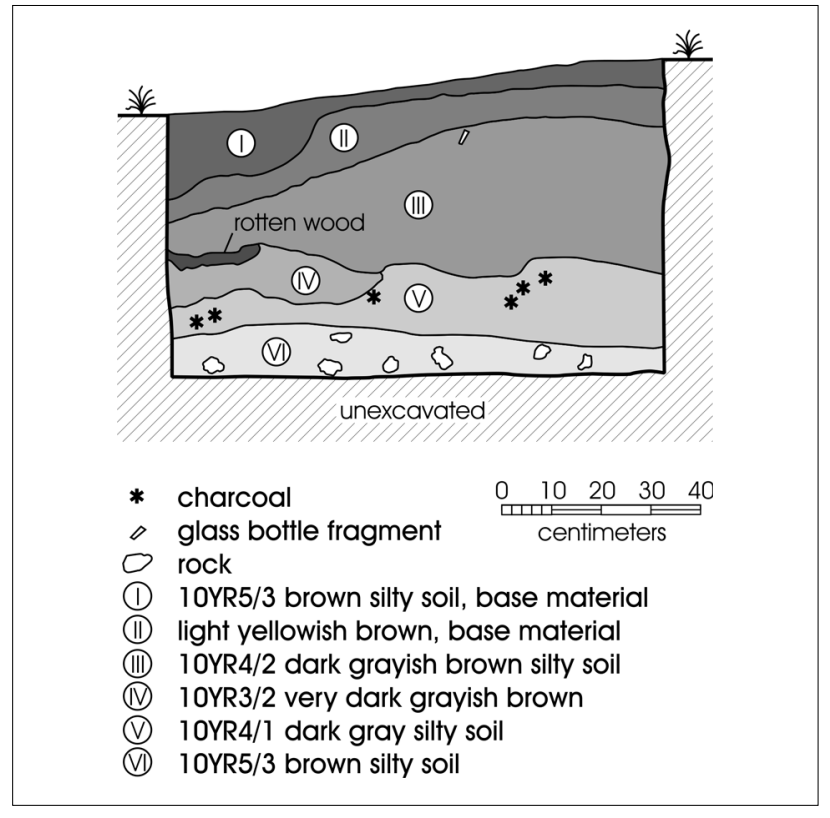

Figure 3-5. Profile of the north wall of Unit $C$. 


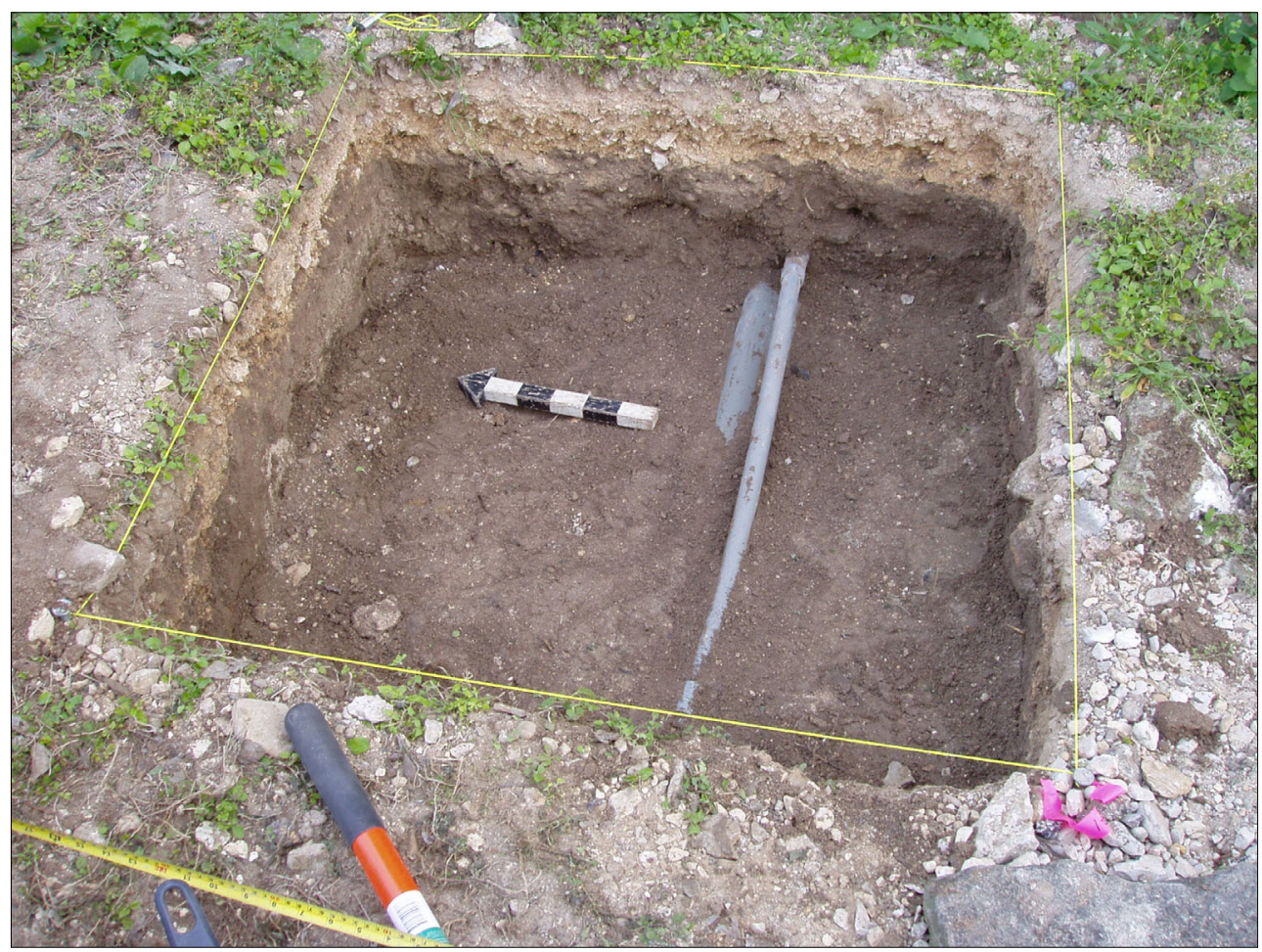

Figure 3-6. Pipes exposed in Unit C.

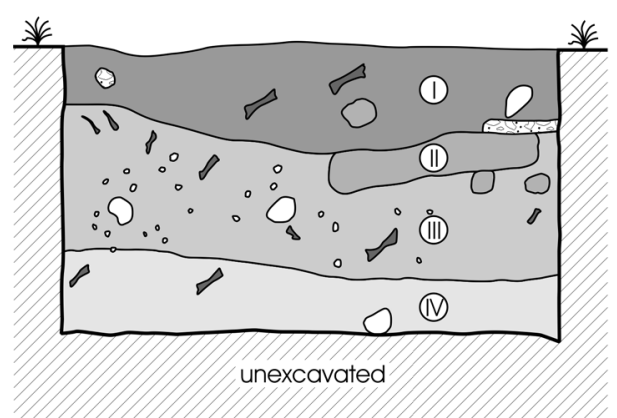

sandstones
limestone
concrete
pebbles
root
(1) 10 YYR5/2 grayish brown, base material
(III) 10YR5/3 silty with small gravel, brown
(IV) 10YR2/2 dark brown, silty loam

Figure 3-7. Profile of the east wall of Unit D.
(40-60 cmbd). This dark brown (10YR 2/2) silty loam zone exhibited fewer disturbances and a decrease in gravel inclusions. Excavation of this unit was terminated at 60 cmbd. Stabilization activity will not impact below $60 \mathrm{~cm}$.

\section{Unit E}

Unit $\mathrm{E}$ was placed on the west side of the convento and abutting the north side of one of the buttresses (see Figure 2-1). Four stratigraphic zones could be distinguished in this unit. Zone I consisted of brownish yellow (10YR 6/6) fill that reached a maximum thickness of $18 \mathrm{~cm}$ and was entirely contained within Level 1. Beneath the fill, a layer of concrete that adjoined the buttress was noted along the south edge of the unit. It extended into the south portion of the unit approximately $20 \mathrm{~cm}$ (Figure 3-8). The remainder of the soil in the unit (Levels 2-4, 20-80 cmbd) consisted of a dark grayish brown silty clay with charcoal and stone inclusions. Stratigraphic Zone II extended through Levels 2-4, while Zone III was contained within Level 4. A 10-inch 
concrete pipe was encountered at $68 \mathrm{cmbd}$ (Figure 3-9). The pipe ran east-west within the unit, and appears to continue under the west wall of the convento. The excavation of Unit E was terminated at $77 \mathrm{cmbd}$.

\section{Unit F}

Unit $\mathrm{F}$ was excavated at the west end of the buttress because the obstructions (i.e., the concrete pipe and concrete abutting the buttress) in Unit E prevented the excavation of the unit to the bottom of the buttress (see Figure 2-1). This unit contained four stratigraphic zones (Figure 3-10). Zone I, the upper $19 \mathrm{~cm}$ of this unit contained within Level 1, consisted of base material (fill), similar to that noted in Unit E. The buttress extended into the southern portion of the unit at $18 \mathrm{cmbd}$. At $19-22 \mathrm{cmbd}$, two distinct soil zones were visible across the unit. The eastern portion of the unit consisted of a zone (Zone II) of dark grayish brown (10YR 3/2) silty loam, with charcoal flecks throughout. This Zone extended through Levels 2-5 (20-100 cmbd), reaching a greatest depth of $100 \mathrm{cmbd}$. Zone III was present in the western half of the unit, and extended through Levels 2-6

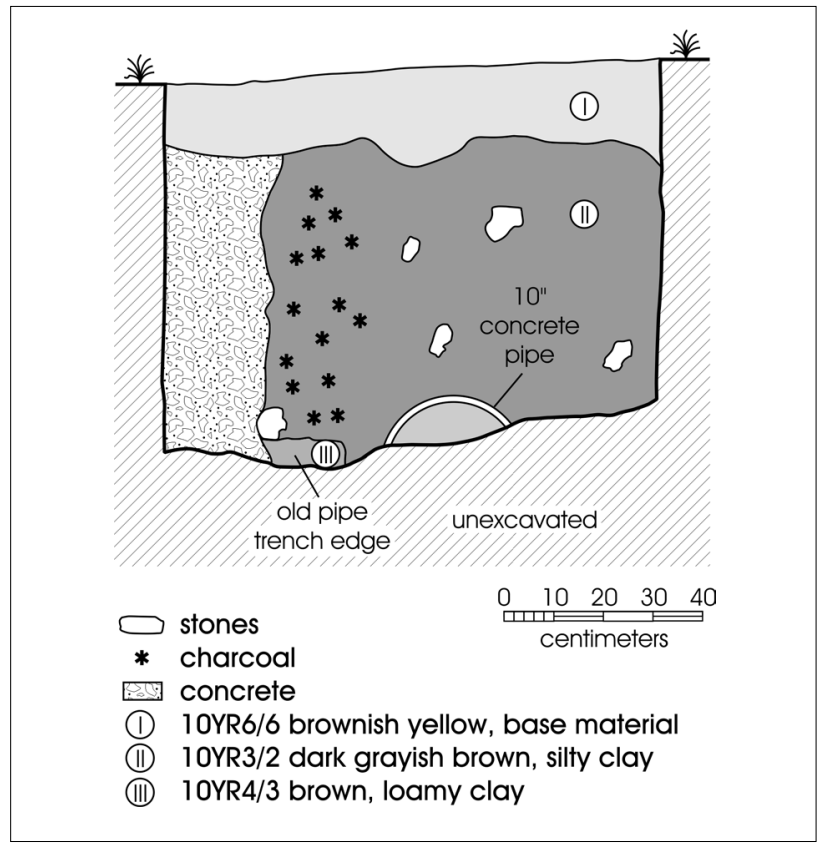

Figure 3-8. Profile of the west wall of Unit E.

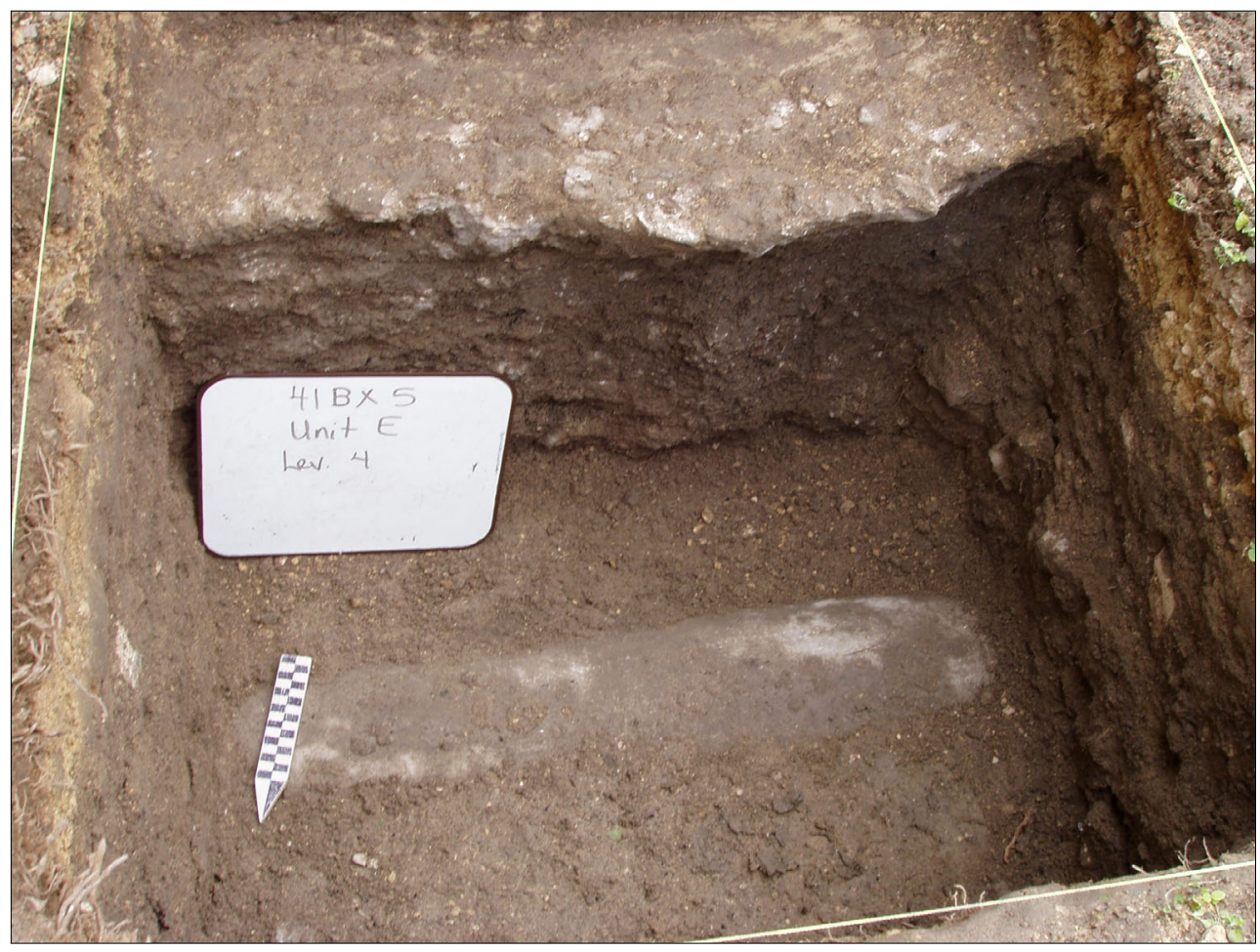

Figure 3-9. Pipe running parallel to buttress in Unit E. 


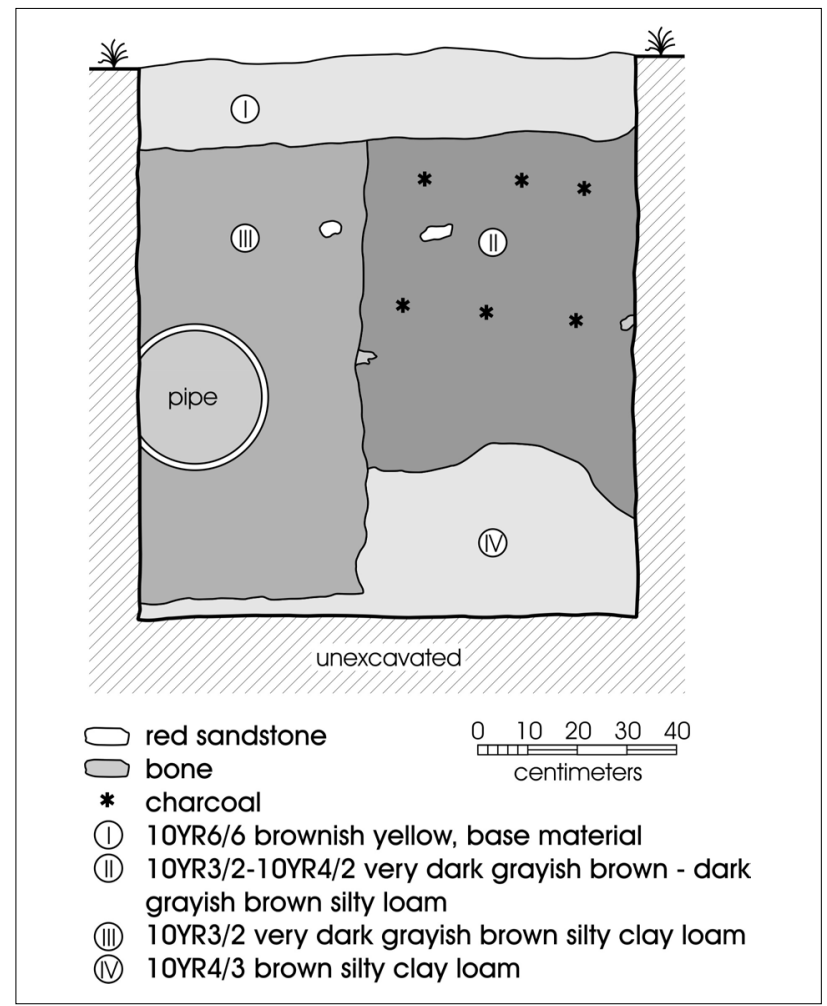

(20-120 cmbd). It had very straight demarcation lines and ended in a flat surface, and represented trench fill (Figure 3-10). It consisted of dark (10YR 3/2) silty clay loam. A pipe was encountered at $54 \mathrm{cmbd}$ and extended to a depth of $80 \mathrm{cmbd}$ (Figure 3-11) within the trench fill (Zone III). Underneath the undisturbed matrix was a brown (10YR 4/3) silty clay loam which, on the west side of the unit, was contained within Level 6. Zone IV was contained within Levels 5 and 6 on the east side of the unit. The bottom of the buttress was encountered at $110 \mathrm{cmbd}$.

Figure 3-10. Profile of the north wall of Unit F.

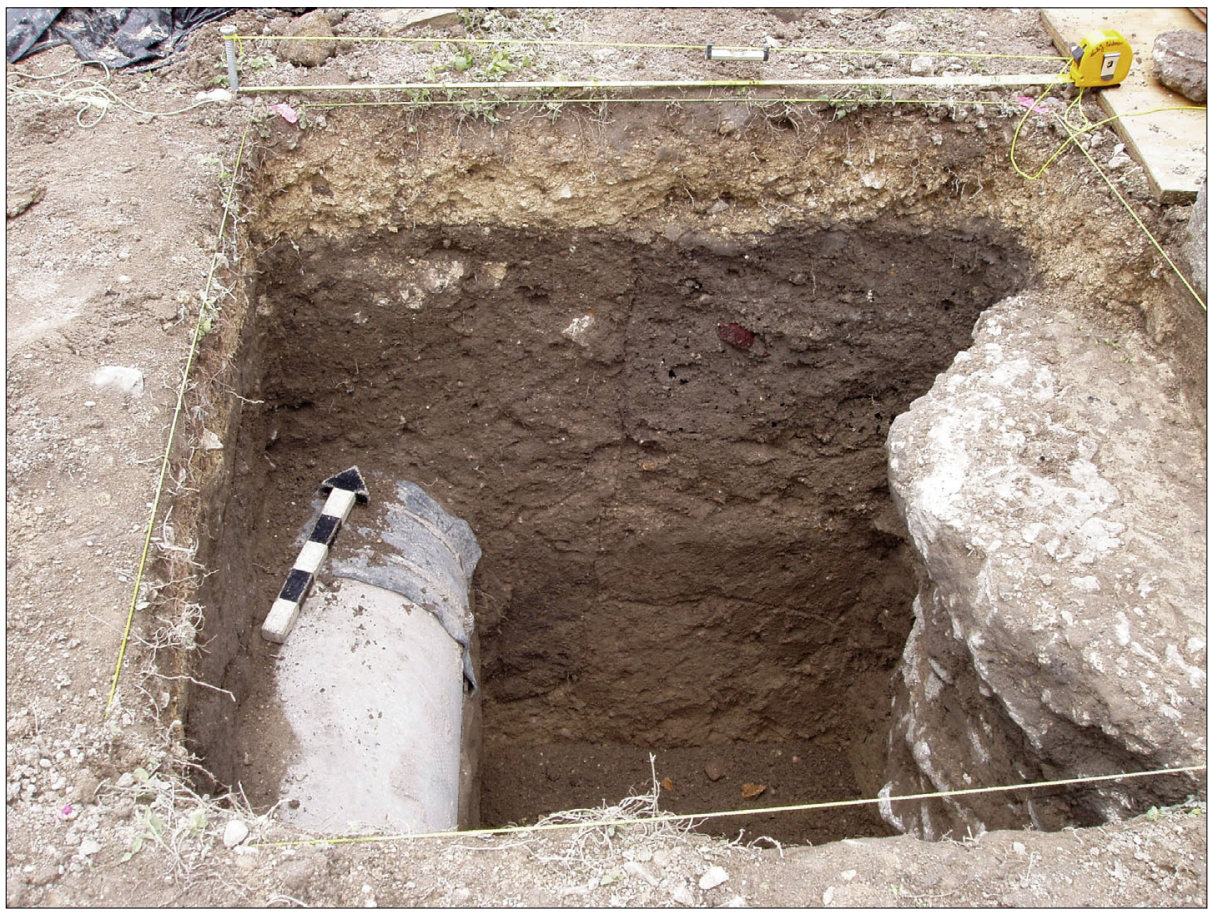

Figure 3-11. Pipe and buttress exposed in Unit F. 


\section{Chapter 4: Artifact Recovery}

\section{Artifacts Recovered from Unit A}

An array of ceramics and other artifacts was recovered from Unit A (Table 4-1). Cultural material recovered from Level 1 of Unit A includes ceramics, bone, glass, metal, snail and mussel shells, debitage, a glass marble, and a sandstone gaming piece. The ceramics encountered in Level 1 consist of stoneware, white earthenware, and Native American Goliad. There was an increase in bone, ceramics, glass and metal in Level 2 (20-40 cmbd). The ceramics types recovered include a Colonial lead-glazed ware, white earthenwares (decorated and undecorated) and Native Goliad ware. In addition, a clay marble, a ceramic gaming piece, a metal button, and a single piece of debitage were recovered from Level 2 . There was a decrease in artifacts in
Level 3 (40-60 cmbd), with the drop accounted for by decreases in ceramics, flat glass, and scrap metal. The few ceramics recovered included white earthenwares $(n=2)$ and a single Goliad specimen. One gunflint was recovered from Level 3. Overall, the highest concentration (49\%) of cultural material in Unit A was recovered from Level 2. Glass fragments were present throughout all of the levels. Colonial, Native, and stoneware ceramics were few in this unit. The most common types of ceramics present were English white earthenwares (76\%). Construction materials such as sandstone, mortar and plaster were also present in Unit A. Based on the artifact assemblage, there does not seem to be an intact Colonial deposit represented in this unit, with modern glass and late-nineteenth-century ceramics in the deepest level.

Table 4-1. Artifacts Recovered from Unit A

\begin{tabular}{|l|c|c|c|c|}
\hline Artifact Category & Level 1 & Level 2 & Level 3 & Total \\
\hline Native American Ceramic: Goliad & 1 & 4 & 1 & 6 \\
\hline Colonial Ceramic: Lead-glazed & & 1 & & 1 \\
\hline English Ceramic: White Earthenware & 4 & 20 & 2 & 26 \\
\hline English Ceramic: Stoneware & 1 & & & 1 \\
\hline Bone & 36 & 154 & 101 & 291 \\
\hline Brick & 10 & 3 & & 13 \\
\hline Burned Chert & 4 & & 1 & 5 \\
\hline Metal Button & & 1 & & 1 \\
\hline Charcoal & 1 & 1 & 1 & 3 \\
\hline Clay Marble & & 1 & & 1 \\
\hline Cut Nail & 2 & & & 2 \\
\hline Debitage & 4 & 1 & 1 & 6 \\
\hline Gaming Piece & 1 & 1 & & 2 \\
\hline Glass & 23 & 69 & 56 & 148 \\
\hline Glass Marble & 1 & & & 1 \\
\hline Gunflint & & & 1 & 1 \\
\hline Metal & 10 & 23 & 6 & 39 \\
\hline Mortar & 3 & 1 & 5 & 9 \\
\hline Mussel Shell & 2 & & 1 & 3 \\
\hline Penny & 131 & 312 & 196 & 639 \\
\hline Plaster & 13 & 31 & 16 & 60 \\
\hline Sandstone & 14 & & & 1 \\
\hline Snail & 1 & & & 2 \\
\hline Wire Nail & & & & \\
\hline Grand Total & & & \\
\hline
\end{tabular}




\section{Artifacts Recovered from Unit B}

Level 1 of Unit B produced moderate numbers of bone and glass with a small amount of debitage and scrap metal (Table 4-2). The ceramics from this level consist of Goliad, Colonial tin-glazed, English stoneware and white earthenware. There was a significantly higher amount of cultural material in Level 2. Increases occurred in nearly all artifact categories except debitage. English white earthenwares and stonewares constitute the bulk of the ceramics from Level 2 (88\%). This level contained minimal numbers of Goliad ware, Colonial wares and porcelains (English and Chinese). In Level 3, artifact counts decrease to nearly Level 1 numbers, with most of the artifacts consisting of animal bones and ceramics. English wares dominate the Level 3 collection (75\%), followed by Goliad wares ( $25 \%$ ). Like Unit A, the majority of artifacts in Unit B are from Level 2 (71\%). Native American and Colonial ceramics are few from this unit but occur in all three levels. English white earthenwares and stonewares were the dominant ceramic types throughout the unit, particularly in Levels 2 and 3. The majority of glass fragments recovered from Unit B also came from Level 2. Disturbance was evident down to $60 \mathrm{cmbd}$ (Level 2) in this unit, with the presence of plastic fragments.

\section{Artifacts Recovered from Unit C}

A small number of artifacts was collected from Level 1 (0-20 cmbd) of Unit C (Table 4-3). As mentioned in the unit and soil descriptions, this level consisted of a gravel fill. Artifacts from this level include an aqua glass fragment, debitage, wire nails, asbestos pipe fragments, a Guanajuato tin-glazed ceramic, and an animal bone. Level 2 (20-40 $\mathrm{cmbd}$ ) exhibited a dramatic increase in artifact density with more than half of the sample consisting of fragments of container glass. Out of the 270 glass fragments from Level $2,72 \%$ is brown glass. A faceted, blue glass bead was also recovered from Level 2. Faunal remains and ceramic sherds also increased in density throughout Level 2. English wares

Table 4-2. Artifacts Recovered from Unit B

\begin{tabular}{|l|c|c|c|c|}
\hline Artifact Category & Level 1 & Level 2 & Level 3 & Total \\
\hline Native American Ceramic: Goliad & 2 & 1 & 7 & 10 \\
\hline Colonial Ceramic: Tin-glazed & 1 & & & 1 \\
\hline Colonial Ceramic: Lead-glazed & & 2 & & 2 \\
\hline Chinese Ceramic: Porcelain & & 1 & & 1 \\
\hline English Ceramic: White Earthenware & 3 & 30 & 21 & 54 \\
\hline English Ceramic: Porcelain & & 3 & & 3 \\
\hline English Ceramic: Lusterware & & 1 & & 1 \\
\hline English Ceramic: Stoneware & 1 & 29 & & 30 \\
\hline Asphalt & 2 & & & 2 \\
\hline Bone & 50 & 150 & 70 & 270 \\
\hline Brick & 5 & 24 & 3 & 32 \\
\hline Burned Chert & 3 & 1 & 4 & 8 \\
\hline Charcoal & & 1 & 1 & 2 \\
\hline Cut Nail & & 1 & & 1 \\
\hline Debitage & 7 & & & 7 \\
\hline Glass & 17 & 320 & 7 & 344 \\
\hline Insulation & 1 & & & 1 \\
\hline Metal & 6 & 16 & 4 & 26 \\
\hline Mortar & & 23 & 5 & 28 \\
\hline Other Glass & 4 & & & 4 \\
\hline Plaster & & & 19 & 19 \\
\hline Plastic Fragments & 108 & 638 & 150 & 896 \\
\hline Sandstone & & 19 & 8 & 30 \\
\hline Snail & & 3 & 1 & 5 \\
\hline Unidentified Nail & & & 3 \\
\hline Wire Nail & & & \\
\hline Grand Total & & & \\
\hline
\end{tabular}


Table 4-3. Artifacts Recovered from Unit C

\begin{tabular}{|l|c|c|c|c|}
\hline Artifact Category & Level 1 & Level 2 & Level 3 & Total \\
\hline Native American Ceramic: Goliad & & 3 & 1 & 4 \\
\hline Colonial Ceramic: Tin-glazed & 1 & & & 1 \\
\hline Colonial Ceramic: Lead-glazed & & 1 & & 1 \\
\hline English Ceramic: White Earthenware & & 9 & 6 & 15 \\
\hline English Ceramic: Copper Lusterware & & 1 & & 1 \\
\hline Asbestos & 3 & & & 3 \\
\hline Asphalt & 4 & & & 4 \\
\hline Bone & 1 & 81 & 85 & 167 \\
\hline Brick & 1 & 2 & 1 & 4 \\
\hline Burned Chert & & 1 & & 1 \\
\hline Cut Nail & & 4 & 2 & 6 \\
\hline Debitage & 1 & 1 & & 2 \\
\hline Glass & 1 & 270 & 100 & 371 \\
\hline Glass Bead & & 1 & & 1 \\
\hline Metal & & 23 & 3 & 26 \\
\hline Mortar & 2 & 2 & 3 & 7 \\
\hline Plaster & & & 3 & 3 \\
\hline Plastic & 1 & & 1 & 2 \\
\hline Sandstone & & 7 & & 7 \\
\hline Snail & & 6 & 3 & 9 \\
\hline Tar & & 6 & 5 & 13 \\
\hline Wire Nail & & & 214 & 649 \\
\hline Grand Total & & & \\
\hline
\end{tabular}

and Goliad specimens make up the bulk of the ceramic collection from the level (Table 4-3). Level 3 (40-60 cmbd) had a decrease in cultural material, mostly attributed to a decrease in the number of glass fragments, ceramics and scrap metal. Ceramics from this level consist of white earthenware $(n=6)$ and one Goliad sherd. Painted plaster was recovered from this level. The majority of cultural material recovered from Unit C was from Level 2 (64\%) in association with a modern pipe disturbance (see Chapter 3). Although English white earthenwares are the most frequent ceramic type in Unit $\mathrm{C}$, the counts are less than those from Units A and B.

\section{Artifacts Recovered from Unit D}

The artifacts recovered from Unit D reflect the extent of disturbance within the first two levels (Table 4-4). Contrary to the other three units, Level 1 contained a large number of glass fragments $(n=528)$. Ceramic types recovered from this level include Goliad, Colonial tin-glazed and lead-glazed, and English white earthenwares. A bent, 1980 penny was collected from Level 1, along with a button, a single piece of debitage, metal fragments and wire nails. The amount of cultural material decreased in Level 2 (20-40 cmbd), with the exception of bone and ceramics which both increased. Level 3 (40-60 cmbd) of Unit D lacked glass fragments. The number of ceramics remained the same as Level 2 and there was a slight increase in bone. Colonial and Native types were the only ceramics present. San Agustín and Puebla Blue on White II majolica fragments were recovered from Level 3 and can be dated to the eighteenth an early nineteenth centuries. One piece of debitage and eight pieces of burned chert were recovered from Level 3. It appears that the first two levels of Unit D were disturbed, while the third level was more intact with the presence of Colonial and Native ceramics and a lack of modern materials.

\section{Artifacts Recovered from Unit E}

Unit E produced a total of 623 artifacts (Table 4-5). The small amount of ceramics $(n=3)$ collected from Level $1(0-20 \mathrm{cmbd})$ consist of nineteenth-century white earthenwares (Table 4-5). Level 1 lacked metal artifacts and contained only 11 glass fragments (Table 4-5). Additional items recovered from Level 1 include bone and construction materials such as sandstone and mortar. Level $2(20-40 \mathrm{cmbd})$ exhibited a dramatic 
Table 4-4. Artifacts Recovered from Unit D

\begin{tabular}{|l|c|c|c|c|}
\hline Artifact Category & Level 1 & Level 2 & Level 3 & Total \\
\hline Native American Ceramic: Goliad & 1 & 4 & 3 & 8 \\
\hline Colonial Ceramic: Tin-glazed & 1 & 1 & 7 & 9 \\
\hline Colonial Ceramic: Lead-glazed & 2 & 3 & 1 & 6 \\
\hline Colonial Ceramic: Burnished & & 1 & & 1 \\
\hline English Ceramic: White Earthenware & 4 & 2 & & 6 \\
\hline Bone & 64 & 102 & 125 & 291 \\
\hline Brick & 3 & & & 3 \\
\hline Burned Chert & & & 8 & 8 \\
\hline Button & 1 & & & 1 \\
\hline Concrete & 1 & & & 1 \\
\hline Cut Nail & & 2 & & 2 \\
\hline Debitage & 1 & & 1 & 2 \\
\hline Glass & 528 & 57 & & 585 \\
\hline Metal & 23 & 2 & & 25 \\
\hline Mortar & & 1 & 1 & 2 \\
\hline Mussel Shell & & 1 & & 1 \\
\hline Plaster & & 2 & & 2 \\
\hline Plastic & 1 & & & 1 \\
\hline Sandstone & 9 & 9 & 3 & 21 \\
\hline USA-Penny & 649 & 187 & 149 & 985 \\
\hline Wire Nail & & & & 9 \\
\hline Grand Total & & & & \\
\hline
\end{tabular}

increase in artifact density, mainly due to an increase in faunal remains and ceramics. The majority of the ceramics recovered consist of nineteenth- to early-twentieth-century white earthenwares (Table 4-5). A moderate number Goliad fragments $(n=8)$ and Colonial wares $(n=6)$ were recovered. Glass $(\mathrm{n}=8)$ and debitage $(\mathrm{n}=1)$ were few in number in this level. Level 3 (40-60 cmbd) had a similar artifact density as the previous level. While there was a slight decrease in ceramics, faunal remains continued to increase in Level 3 $(\mathrm{n}=163)$. White earthenwares $(65 \%)$, Colonial tin-glazed and lead-glazed wares continued in Level 3, along with Native Goliad sherds $(\mathrm{n}=7)$. Level $4(60-80 \mathrm{cmbd})$ exhibited a decrease in cultural material. Only 15 ceramic sherds were collected, the majority of which (53\%) consist of English white earthenwares and stonewares. Faunal remains comprise the largest portion of the artifact assemblage from Level $4(\mathrm{n}=100)$, while there are a small number of glass fragments ( $\mathrm{n}=5)$, metal fragments $(\mathrm{n}=4)$, and debitage $(\mathrm{n}=2)$. The majority of cultural material recovered was from Levels 2 and 3. This unit was disturbed by a pipe that was encountered in Level 4.

\section{Artifacts Recovered from Unit F}

Unit $\mathrm{F}$ excavations produced an abundance of ceramics and other artifacts (Table 4-6). Ceramics recovered from Level 1 consisted of Colonial tin-glazed $(n=1)$, undecorated white earthenware $(\mathrm{n}=1)$, and four Goliad specimens. Other artifacts from Level 1 included bone, glass, nails and other metal. There was a increase in cultural material in Level 2, specifically in metal, bone and ceramics. Ceramics from Level 2 include Colonial lead-glazed and tin-glazed wares, English stoneware, Copper Lusterware, and decorated and undecorated white earthenwares, and Goliad ware. There was a dramatic increase in bone and ceramics in Level 3. Of the ceramics recovered from Level 3, 56\% are Goliad wares, while $31 \%$ are white earthenwares. The remaining ceramics from the level include Colonial tin-glazed (3\%), lead-glazed $(9 \%)$, and burnished wares $(1 \%)$. There was a significant decrease in artifact numbers in Level 4 with animal bone, ceramics, glass, brick, mortar and rock making up most of the assemblage. Ceramics from this level include Colonial lead-glazed and tin-glazed wares, English 
Table 4-5. Artifacts Recovered from Unit E

\begin{tabular}{|c|c|c|c|c|c|}
\hline Artifact Category & Level 1 & Level 2 & Level 3 & Level 4 & Total \\
\hline Native American Ceramic: Goliad & & 8 & 7 & 3 & 18 \\
\hline Colonial Ceramic: Tin-glazed & & 1 & 2 & & 3 \\
\hline Colonial Ceramic: Lead-glazed & & 5 & 3 & 3 & 11 \\
\hline English Ceramic: Yellowware & & & 1 & & 1 \\
\hline English Ceramic: White Earthenware & 3 & 15 & 10 & 6 & 34 \\
\hline English Ceramic: Stoneware & & & & 2 & 2 \\
\hline Unknown Ceramic: Unglazed & & & & 1 & 1 \\
\hline Bone & 3 & 113 & 163 & 100 & 379 \\
\hline Brick & 1 & 21 & 14 & 18 & 54 \\
\hline Burned Clay & & & & 1 & 1 \\
\hline Button & & & 1 & & 1 \\
\hline Charcoal & & 1 & 1 & & 2 \\
\hline Cut Nail & & & 1 & & 1 \\
\hline Debitage & & 1 & & 2 & 3 \\
\hline Glass & 11 & 8 & 13 & 5 & 37 \\
\hline Metal & & 2 & 13 & 4 & 19 \\
\hline Mortar & 1 & & 4 & 3 & 8 \\
\hline Mussel Shell & & 1 & & & 1 \\
\hline Other Glass & & 2 & & & 2 \\
\hline Plaster & & & 3 & & 3 \\
\hline Plastic & & 19 & & & 19 \\
\hline Sandstone & 2 & 7 & 1 & 5 & 15 \\
\hline Slate Fragment & & & & 1 & 1 \\
\hline Snail & 3 & & 1 & 1 & 5 \\
\hline String & 1 & & & & 1 \\
\hline \begin{tabular}{|l|} 
Wire Nail \\
\end{tabular} & & 1 & & & 1 \\
\hline Grand Total & 25 & 205 & 238 & 155 & 623 \\
\hline
\end{tabular}

undecorated white earthenware, and Goliad ware. Levels 5 and 6 contained few artifacts. Ceramics from these levels include Colonial lead-glazed and tin-glazed wares, and English undecorated and decorated white earthenwares. The majority of the cultural material from Unit F came from Levels 2 and 3, with a high percentage of ceramics and bone. As compared with the other units, there was very little glass from Unit F. 
Table 4-6. Artifacts Recovered from Unit F

\begin{tabular}{|c|c|c|c|c|c|c|c|}
\hline Artifact Category & Level 1 & Level 2 & Level 3 & Level 4 & Level 5 & Level 6 & Total \\
\hline Native American Ceramic: Goliad & 4 & 14 & 43 & 12 & 5 & 2 & 80 \\
\hline Colonial Ceramic: Tin-glazed & 1 & 2 & 2 & 1 & 1 & & 7 \\
\hline Colonial Ceramic: Lead-glazed & & 4 & 7 & 1 & 1 & & 13 \\
\hline Colonial Ceramic: Burnished & & & 1 & & & & 1 \\
\hline English Ceramic: White Earthenware & 1 & 36 & 24 & 3 & 7 & 1 & 72 \\
\hline English Ceramic: Stoneware & & 2 & & & & & 2 \\
\hline English Ceramic: Copper Lusterware & & 1 & & & & & 1 \\
\hline Bone & 9 & 167 & 1302 & 141 & 59 & 18 & 1696 \\
\hline Brick & 5 & 10 & 8 & 12 & 6 & 3 & 44 \\
\hline Burned Chert & & 2 & & 4 & 2 & & 8 \\
\hline Burned Limestone & & 1 & & & & & 1 \\
\hline Button & 1 & 3 & & & & & 4 \\
\hline Charcoal & & 1 & 1 & & 1 & & 3 \\
\hline Cut Nail & 3 & & 2 & & & & 5 \\
\hline Debitage & 1 & & 1 & & 1 & & 3 \\
\hline Glass & 15 & 15 & 10 & 5 & 3 & 3 & 51 \\
\hline Metal & 1 & 11 & 2 & & 1 & & 15 \\
\hline Mortar & & 19 & 19 & 10 & 4 & 1 & 53 \\
\hline Mussel Shell & & & & & & 1 & 1 \\
\hline Plaster & 1 & 4 & 47 & & & 1 & 53 \\
\hline Plastic & & & 1 & & & & 1 \\
\hline Pond's Cold Cream Lid & & & 1 & & & & 1 \\
\hline Roofing Nail & & & & & & 1 & 1 \\
\hline Sandstone & & 6 & 21 & 4 & 2 & 1 & 34 \\
\hline Snail & 1 & & & & & 3 & 4 \\
\hline Wire Nail & 2 & 7 & & & & & 9 \\
\hline Grand Total & 45 & 305 & 1492 & 193 & 93 & 35 & 2163 \\
\hline
\end{tabular}




\section{Chapter 5: Artifact Classification and Analysis}

The six unit excavations produced a mixture of Spanish Colonial, nineteenth-century and twentieth-century artifacts. The types of artifacts recovered from excavations included ceramics, glass, chipped stone, burned rock, animal bone, metals, personal and activity items, and mussel shell. For a better understanding of the distribution of artifacts, this chapter will discuss the artifacts by class and type. Construction items such as asphalt, sandstone, tar, mortar, and plaster were recovered from most of the units, along with modern materials. These items will not be discussed in this section, but instead can be found listed in the individual unit tables. Analyses were conducted on the vertebrate faunal remains and Goliad wares.

\section{Glass}

There was a large number of glass fragments recovered during the excavations ( $\mathrm{n}=1,536$; Table 5-1). Various colors of glass were present in all of the units. Eighteen percent of the glass fragments recovered are olive (eighteenth- to earlynineteenth-century) and they were usually recovered with modern brown and clear glass fragments. Brown was the most dominant glass present in the units $(49 \%)$. Other glass colors present in the collection include amber, aqua, clear, green, pink, purple and red.

\section{Chipped Lithic Artifacts and Burned Chert}

A total of 24 chipped stone artifacts was collected from excavations (Table 5-2). All the units contained lithic debitage. The majority of the lithic debitage is from Unit B $(n=15)$. One gunflint was recovered from Level 3 of Unit A. The gunflint appears to be bifacially worked (Villalobos 2003) and measures $24 \mathrm{~mm}$ in length, $22 \mathrm{~mm}$ in width and 5 $\mathrm{mm}$ in thickness. It appears that all of the debitage was produced from local chert. Burned chert was recovered from Units A, B, C, D and F.

Table 5-1. Glass Recovered from Excavations

\begin{tabular}{|c|c|c|c|c|c|c|c|c|c|c|c|c|c|}
\hline & & \multicolumn{11}{|c|}{ Glass Color } & \multirow[b]{2}{*}{ Total } \\
\hline Unit & Level & Amber & Aqua & Blue & Brown & Clear & Green & Lamp & Olive & Pink & Purple & Red & \\
\hline \multirow{3}{*}{ A } & 1 & & 1 & & 3 & 14 & 1 & 1 & 3 & & & & 23 \\
\hline & 2 & & 22 & & 12 & 29 & & & 6 & & & & 69 \\
\hline & 3 & & 4 & 4 & 27 & 16 & & & 5 & & & & 56 \\
\hline \multirow{3}{*}{ B } & 1 & & 1 & & 5 & 8 & 1 & & 1 & & 1 & & 17 \\
\hline & 2 & & 8 & & 212 & 84 & 12 & & 4 & & & & 320 \\
\hline & 3 & & 2 & & 1 & 2 & & & 2 & & & & 7 \\
\hline \multirow{3}{*}{ C } & 1 & & 1 & & & & & & & & & & 1 \\
\hline & 2 & & 6 & & 198 & 45 & 3 & & 17 & & 1 & & 270 \\
\hline & 3 & & 16 & & 39 & 21 & 1 & & 23 & & & & 100 \\
\hline \multirow{2}{*}{ D } & 1 & & 3 & & 187 & 61 & 272 & & 5 & & & & 528 \\
\hline & 2 & & 1 & & 42 & 13 & 1 & & & & & & 57 \\
\hline \multirow{4}{*}{$\mathrm{E}$} & 1 & & 1 & & 1 & 9 & & & & & & & 11 \\
\hline & 2 & & 1 & & 2 & 2 & & & 3 & & & & 8 \\
\hline & 3 & & 2 & & 4 & 3 & 1 & & 1 & & 1 & 1 & 13 \\
\hline & 4 & & 2 & & 1 & 2 & & & & & & & 5 \\
\hline \multirow{6}{*}{$\mathrm{F}$} & 1 & & & & 10 & 5 & & & & & & & 15 \\
\hline & 2 & 1 & 1 & & 4 & 5 & 1 & & 3 & & & & 15 \\
\hline & 3 & & 2 & & 2 & & 1 & & 4 & 1 & & & 10 \\
\hline & 4 & & 1 & & 1 & 2 & & & 1 & & & & 5 \\
\hline & 5 & & 1 & & & 2 & & & & & & & 3 \\
\hline & 6 & & & & 2 & 1 & & & & & & & 3 \\
\hline \multicolumn{2}{|c|}{ Total } & 1 & $\overline{76}$ & 4 & 753 & 324 & 294 & 1 & 78 & 1 & 3 & 1 & 1536 \\
\hline
\end{tabular}


Table 5-2. Chipped Stone and Burned Chert Recovered from Excavations

\begin{tabular}{|c|c|c|c|c|c|}
\hline Unit & Level & Burned Chert & Debitage & Gunflint & Total \\
\hline \multirow{3}{*}{ A } & 1 & 4 & 4 & & 5 \\
\hline & 2 & & 1 & & 1 \\
\hline & 3 & 1 & 1 & 1 & 3 \\
\hline \multirow{3}{*}{ B } & 1 & 3 & 7 & & 10 \\
\hline & 2 & 1 & & & 1 \\
\hline & 3 & 4 & & & 4 \\
\hline \multirow{2}{*}{$\mathrm{C}$} & 1 & & 1 & & 1 \\
\hline & 2 & 1 & 1 & & 2 \\
\hline \multirow{2}{*}{$\mathrm{D}$} & 1 & & 1 & & 1 \\
\hline & 3 & 8 & 1 & & 9 \\
\hline \multirow{2}{*}{$\mathrm{E}$} & 2 & & 1 & & 1 \\
\hline & 4 & & 2 & & 2 \\
\hline \multirow{5}{*}{$\mathrm{F}$} & 1 & & 1 & & 1 \\
\hline & 2 & 2 & & & 2 \\
\hline & 3 & & 1 & & 1 \\
\hline & 4 & 4 & & & 4 \\
\hline & 5 & 2 & 1 & & 3 \\
\hline \multicolumn{2}{|c|}{ Total } & 30 & 23 & 1 & 54 \\
\hline
\end{tabular}

\section{Metal}

Metal items are common artifacts at mission sites. The excavations produced a variety of metal artifacts $(n=209)$ from all six units (Table 5-3). Most of the metal recovered from the units consists of unidentifiable metal fragments $(n=104)$. Cut nails, wire and unidentified nails are present in the assemblage. The other metal objects present include a bottle cap, a can key, crown caps $(n=12)$, pull tabs $(n=2)$, metal fasteners ( $n=8$; e.g., screws, spikes, bolts and nuts), tin can fragments $(n=5)$ and a harmonica reed.

\section{Personal and Activity Items}

The items in this class range from personal items such as buttons to activity items such as clay marbles and gaming pieces (Table 5-4). A total of seven buttons was recovered from Units A, D, E, and F. The buttons are composed of different materials, such as porcelain $(n=2)$, bone $(n=2)$, plastic $(n=1)$, vegetable ivory $(n=1)$, and metal $(n=1)$. Two marbles were recovered from Unit A. The marble from Level 1 is made of transparent glass. These types of marbles began to be produced in the late 1880s (Zapata 1997). A clay marble was recovered from Level 2 of Unit A. It is tan in color and about $14 \mathrm{~mm}$ in diameter, and appears to be handmade. These marbles, typically known as "commies" or common clay, were manufactured by children and range in date from 1840 to 1920 (Zapata 1997).

Two disc-shaped pieces (gaming pieces) were recovered from Unit A. One is made of ceramic and the other of sandstone. These discs were classified as gaming pieces or cuatros. They are usually found in historical contexts (Zapata et al. 2000). These items have been reported in mission contexts, but there are no solid dates for their use (Zapata et al. 2000). Additional items of interest recovered from excavations included two coins (pennies) and a Pond's cold cream jar lid. As mentioned previously, one faceted, blue glass bead was recovered from Level 2 of Unit C. One fragment of slate was also recovered from Unit E. 
Table 5-3. Metal Artifacts Recovered from Excavations

\begin{tabular}{|c|c|c|c|c|c|c|c|c|c|c|c|c|c|c|}
\hline Unit & Level & $\begin{array}{l}\text { Bottle } \\
\text { Cap }\end{array}$ & $\begin{array}{l}\text { Can } \\
\text { Key }\end{array}$ & $\begin{array}{c}\text { Crown } \\
\text { Cap }\end{array}$ & Fastener & Fragment & $\begin{array}{c}\text { Harmonica } \\
\text { Reed }\end{array}$ & Nail & Pipe & $\begin{array}{l}\text { Pull } \\
\text { Tab }\end{array}$ & Rivet & $\begin{array}{l}\text { Tin } \\
\text { Can }\end{array}$ & Misc. & Total \\
\hline \multirow{3}{*}{ A } & 1 & & & & 1 & 9 & & 3 & & & & & & 13 \\
\hline & 2 & & & & 1 & 15 & & 7 & & & & & & 23 \\
\hline & 3 & & & & 1 & & & & & & & 5 & & 6 \\
\hline \multirow{3}{*}{ B } & 1 & & 1 & & 2 & 1 & & & & & & & 2 & 6 \\
\hline & 2 & 1 & & 6 & 1 & 5 & & 10 & & & & & 3 & 26 \\
\hline & 3 & & & & & 4 & & & & & & & & 4 \\
\hline \multirow{3}{*}{$\mathrm{C}$} & 1 & & & & & & & 2 & & & & & & 2 \\
\hline & 2 & & & 1 & & 21 & & 10 & & & 1 & & & 33 \\
\hline & 3 & & & & 1 & & 1 & 7 & & & 1 & & & 10 \\
\hline \multirow{2}{*}{ D } & 1 & & & 5 & & 15 & & 9 & 1 & 1 & & & 1 & 32 \\
\hline & 2 & & & & & 2 & & 2 & & & & & & 4 \\
\hline \multirow{3}{*}{ E } & 2 & & & & & 2 & & & & & & & & 2 \\
\hline & 3 & & & & & 13 & & 1 & & & & & & 14 \\
\hline & 4 & & & & & 4 & & & & & & & & 4 \\
\hline \multirow{5}{*}{$\mathrm{F}$} & 1 & & & & & & & 5 & & 1 & & & & 6 \\
\hline & 2 & & & & & 11 & & 7 & & & & & & 18 \\
\hline & 3 & & & & 1 & 1 & & 2 & & & & & & 4 \\
\hline & 5 & & & & & 1 & & & & & & & & 1 \\
\hline & 6 & & & & & & & 1 & & & & & & 1 \\
\hline \multicolumn{2}{|c|}{ Total } & 1 & 1 & 12 & 8 & 104 & 1 & 66 & 1 & 2 & 2 & 5 & 6 & 209 \\
\hline
\end{tabular}

Table 5-4. Personal and Activity Items Recovered from Excavations

\begin{tabular}{|c|c|c|c|c|c|c|c|c|c|c|}
\hline Unit & Level & $\begin{array}{l}\text { Glass } \\
\text { Bead }\end{array}$ & Button & $\begin{array}{c}\text { Clay } \\
\text { Marble }\end{array}$ & $\begin{array}{c}\text { Glass } \\
\text { Marble }\end{array}$ & $\begin{array}{c}\text { Gaming } \\
\text { Piece }\end{array}$ & Coin & $\begin{array}{l}\text { Pond's } \\
\text { Lid }\end{array}$ & Slate & Total \\
\hline \multirow{3}{*}{ A } & 1 & & & & 1 & 1 & & & & 2 \\
\hline & 2 & & 1 & 1 & & 1 & 1 & & & 4 \\
\hline & 4 & & & & & & & & & 1 \\
\hline $\mathrm{C}$ & 2 & 1 & & & & & & & & 1 \\
\hline $\mathrm{D}$ & 1 & & 1 & & & & 1 & & & 2 \\
\hline \multirow{2}{*}{ E } & 3 & & 1 & & & & & & & 1 \\
\hline & 4 & & & & & & & & 1 & \\
\hline \multirow{3}{*}{$\mathrm{F}$} & 1 & & 1 & & & & & & & 1 \\
\hline & 2 & & 3 & & & & & & & 3 \\
\hline & 3 & & & & & & & 1 & & 1 \\
\hline \multicolumn{2}{|c|}{ Total } & 1 & 7 & 1 & 1 & 2 & 2 & 1 & 1 & 16 \\
\hline
\end{tabular}




\section{Animal Bone, Mussel Shell and Snail Shell}

Excavations produced a small amount of snail and mussel shell (Table 5-5). During the lab processing, only whole snail shells and mussel umbos were kept. A total of seven mussel shell umbos were recovered in Units A, D, E and F. Species identified included one Amblema plicata (Threeridge) specimen and one Tritogonia verrucosa (Pistolgrip) specimen. Five different snail genera were identified out of the 39 specimens. The identified genera included Rabdotus, Pachychilus, Practicolella, Helicina and Polygyra. A large quantity of animal bone was recovered from the units $(\mathrm{n}=2,334$; Table 5-5). The following section presents a discussion of the identification and analysis of the bone. A single human metacarpal was identified in the collection. It was recovered from Unit E, Level 1.

\section{Analysis of Vertebrate Faunal Remains}

\section{Methods}

A total of 2,334 pieces of animal bone weighing 4,646.66 grams was analyzed from the excavation of Units A-F at Mission San Juan (Table 5-6).

Each specimen was identified to the lowest taxonomic level possible using the CAR comparative collection and identification manuals (Balkwill and Cumbaa 1992; Boessneck 1970; Brown and Gustafson 1979; Gilbert 1990; Hildebrand 1955; Hillson 1986; Olsen 1964, 1968, 1969; Sobolik and Steele 1996). As it is difficult to distinguish between elements of deer, pronghorn antelope, goat, and sheep, many Artiodactyla specimens of the size of these species were recorded simply as "Artiodactyla." Bovine

Table 5-5. Animal Bone and Shell Recovered from Excavations

\begin{tabular}{|c|c|c|c|c|c|}
\hline Unit & Level & Bone & Mussel Shell & Snail Shell & Total \\
\hline \multirow{3}{*}{ A } & 1 & 34 & 2 & 14 & 50 \\
\hline & 2 & 133 & & & 133 \\
\hline & 3 & 95 & & 2 & 97 \\
\hline \multirow{3}{*}{ B } & 1 & 45 & & 3 & 48 \\
\hline & 2 & 134 & & 1 & 135 \\
\hline & 3 & 65 & & 1 & 66 \\
\hline \multirow{3}{*}{$\mathrm{C}$} & 1 & 1 & & & 1 \\
\hline & 2 & 80 & & 6 & 86 \\
\hline & 3 & 81 & & 3 & 84 \\
\hline \multirow{3}{*}{ D } & 1 & 51 & & & 51 \\
\hline & 2 & 93 & 1 & & 94 \\
\hline & 3 & 134 & & & 134 \\
\hline \multirow{4}{*}{ E } & 1 & 3 & & 3 & 6 \\
\hline & 2 & 108 & 1 & & 109 \\
\hline & 3 & 151 & 2 & 1 & 154 \\
\hline & 4 & 95 & & 1 & 96 \\
\hline \multirow{6}{*}{$\mathrm{F}$} & 1 & 9 & & 1 & 10 \\
\hline & 2 & 194 & & & 194 \\
\hline & 3 & 630 & & & 630 \\
\hline & 4 & 125 & & & 125 \\
\hline & 5 & 56 & & & 56 \\
\hline & 6 & 17 & 1 & 3 & 21 \\
\hline \multicolumn{2}{|c|}{ Total } & 2334 & 7 & 39 & 2380 \\
\hline
\end{tabular}


Table 5-6. Vertebrate Faunal Remains Recovered from Excavations

\begin{tabular}{|c|c|c|c|}
\hline Taxa Identified & Common Name & Count & Weight (g) \\
\hline Artiodactyla & goat/sheep/deer/pronghorn & 21 & 207.43 \\
\hline Bos taurus & cattle & 19 & 474.38 \\
\hline Bovidae & cattle/bison & 59 & 1192.90 \\
\hline Canis familiaris & domestic dog & 1 & 14.30 \\
\hline Canis sp. & unidentified canid & 2 & 7.18 \\
\hline Capra/Ovis Total & goat/sheep & 7 & 37.27 \\
\hline CF Capra & goat? & 1 & 14.04 \\
\hline Didelphis virginianus & opossum & 1 & 3.60 \\
\hline Equus sp. & horse & 2 & 44.81 \\
\hline CF Equus & horse? & 1 & 11.83 \\
\hline Homo sapiens & human & 1 & 1.91 \\
\hline Lepus sp. & jackrabbit & 1 & 0.24 \\
\hline Neotoma sp. & wood rat & 1 & 0.12 \\
\hline Odocoileus virginianus & white-tailed deer & 2 & 44.14 \\
\hline Odocoileus sp. & white-tailed/mule deer & 7 & 62.80 \\
\hline Peccari tajacu & collared peccary & 2 & 13.75 \\
\hline Sigmodon hispidus & Hispid cotton rat & 1 & 0.30 \\
\hline Sus scrofa & pig & 2 & 24.36 \\
\hline Sylvilagus sp. & cottontail rabbit & 1 & 0.43 \\
\hline Gallus domesticus & chicken & 2 & 2.91 \\
\hline Ictalurus sp. & catfish & 2 & 0.29 \\
\hline Pylodictus olivaris & flathead catfish & 1 & 0.33 \\
\hline Trionyx sp. & softshell turtle & 1 & 3.61 \\
\hline Identified Subtotal & & 138 & 2162.93 \\
\hline \multicolumn{4}{|l|}{ Unidentified Remains } \\
\hline large mammal & & 72 & 611.09 \\
\hline medium mammal & & 54 & 173.83 \\
\hline medium/large mammal & & 1 & 0.88 \\
\hline small mammal & & 6 & 1.68 \\
\hline unidentified rodent & & 11 & 2.13 \\
\hline unidentified mammal & & 1619 & 1558.21 \\
\hline large bird & & 2 & 15.90 \\
\hline unidentified bird & & 20 & 12.19 \\
\hline unidentified fish & & 18 & 9.77 \\
\hline unidentified turtle & & 3 & 5.51 \\
\hline unidentified & & 390 & 92.54 \\
\hline Unidentified Subtotal & & 2196 & 2483.73 \\
\hline Grand Total & & 2334 & 4646.66 \\
\hline
\end{tabular}


specimens that could not be clearly identified as cattle or bison were recorded as Bovidae. Although it is unlikely the unidentified bovid specimens are those of bison, they were conservatively identified as simply bovid.

The observations made on each specimen included element, portion, side, burning, breaks, and modifications. The degree of burning was recorded as unburned, burned, or calcined. Modifications recorded included cut marks, chop marks, impact scars, and saw marks. Green (spiral) breaks were noted as well. Carnivore chewing and rodent gnawing was also recorded.

\section{Results}

Forty-four percent $(n=1,031)$ of the faunal specimens, accounting for $55 \%$ of the total weight $(2,534.19 \mathrm{~g})$, was derived from Unit $F$ (Table 5-7). Unit $E$ produced the next highest number of specimens with 357 (15\%) accounting for $17 \%(804.82 \mathrm{~g})$ of the total weight. The average bone weight for the entire assemblage is two grams.

\section{Identified Taxa}

The identified specimens consist of 17 different genera of mammals, birds, fish, and reptiles (see Table 5-6). Much of the bone is very fragmented, with only $138(6 \%)$ specimens identifiable to at least the family level (see Table 5-6). This small sample of identifiable specimens constitutes $47 \%$ of the assemblage by weight. The majority of the identified specimens, by count and weight, are bovid.

A single human metacarpal fragment was recovered from Level 1 in Unit E. This unit had been disturbed by a 10-inch pipe running through it.

Table 5-7. Counts, Weights and Percentages of Faunal Material Recovered from Units

\begin{tabular}{|c|c|c|c|c|}
\hline Unit & Count & \% of Total & Weight (g) & \% of Total \\
\hline A & 262 & 11 & 289.43 & 6 \\
\hline B & 244 & 11 & 461.29 & 10 \\
\hline C & 162 & 7 & 201.69 & 4 \\
\hline D & 278 & 12 & 355.24 & 8 \\
\hline E & 357 & 15 & 804.82 & 17 \\
\hline F & 1031 & 44 & 2534.19 & 55 \\
\hline Total & 2334 & 100 & 4646.66 & 100 \\
\hline
\end{tabular}

\section{Elements Identified}

The most numerous identified elements are those of the axial skeleton, including the crania $(n=131)$, with most being from medium and large mammals $(n=49)$. Vertebrae $(n=53)$ and ribs $(n=47)$ make up the majority of the axial elements. These are all from medium and large mammals, except for four fish and two unidentified small mammal vertebrae and two unidentified small mammal ribs.

Distal limb elements (metapodials, carpals, tarsals, and phalanges) make up the second most common identified group of elements $(n=45)$. There were relatively few long bones identified $(n=28)$. These consist mostly of bovid, deer and unidentified artiodactyls, although a rabbit femur, a bird humerus and radius, a turtle humerus, and five rodent femurs and a humerus were also identified. A large number of unidentified long bone fragments were noted in the assemblage $(n=57)$. Forty-five of these are from large and medium mammals, with the remaining being bird $(n=11)$ and turtle $(\mathrm{n}=1)$.

Seven pelvic fragments were identified; they consist of two bovid, one goat/sheep, one deer, one unidentified artiodactyl, and two rodent specimens.

A total of 28 individual complete and fragmented teeth was identified in the collection. The identified teeth consist of horse $(n=2)$, cattle/bison $(n=6)$, and goat/sheep $(n=2)$. The remaining unidentified specimens are fragments from large and medium mammals and rodents (one incisor).

Very few paired elements that could be identified to side were present in the assemblage $(n=72)$. Many of them are single specimens of a genus or are from unidentified artiodactyls, small mammals, birds, and fish. The two categories that contained multiple elements are cattle/bison and deer and the minimum number of individuals (MNI) from each of these is two. Given the small number of identified elements and the fact that they come from individual units spread over a large area, the calculation of MNI for this collection is meaningless.

\section{Burning}

There were relatively few burned specimens in the assemblage $(n=42)$. More than half of the burned bones came from Unit $F(n=22)$. Trench fill and a pipe were encountered during excavation of this unit. 


\section{Modifications}

There were 83 specimens with intentional modification (Table 5-8). The modifications included 21 specimens with thin, shallow cut marks, 35 with chop marks, two with both cut and chop marks, and two that had been sawed. One of the sawed specimens is a cattle scapula that had been machine sawed and the other is a small, unidentified fragment. The majority of the chopped elements are vertebrae $(n=15)$ and ribs $(n=8)$. There are also 23 specimens with impact scars. Eighteen of the these are fragments of long bone shafts which all had spiral breaks. These are most likely the result of smashing the bone to extract marrow and/or grease. Marrow extraction involves breaking the bone, usually at the midpoint of the diaphysis, to remove the marrow (Binford 1981).

There are 121 specimens with green (spiral) breaks in the assemblage. Spiral breaks are indicative of the bone being broken, intentionally or otherwise, while it was still fresh. More than half $(n=66)$ of the bones with green breaks are

Table 5-8. Type and Frequency of Modifications to Vertebrate Remains

\begin{tabular}{|c|c|c|c|c|c|c|c|}
\hline Taxon & Element & Cut & Chop & Cut \& Chop & Impact Scar & Sawed & Total \\
\hline \multirow{4}{*}{ Artiodactyla } & central +4 th tarsal & 1 & & & & & 1 \\
\hline & cervical vertebra & & 1 & & & & 1 \\
\hline & humerus & & & & 1 & & 1 \\
\hline & thoracic vertebra & & 2 & & & & 2 \\
\hline \multirow{3}{*}{ Bos taurus } & central +4 th tarsal & 1 & & & & & 1 \\
\hline & middle phalanx & 1 & & & & & 1 \\
\hline & scapula & & & & & 1 & 1 \\
\hline \multirow{8}{*}{ Bovidae } & cervical vertebra & & 1 & & & & 1 \\
\hline & distal sesamoid & 1 & & & & & 1 \\
\hline & humerus & & & & 2 & & 2 \\
\hline & lumbar vertebra & & 4 & & & & 4 \\
\hline & pelvis & & 1 & & & & 1 \\
\hline & rib & & 6 & & & & 6 \\
\hline & scapula & & & & 1 & & 1 \\
\hline & thoracic vertebra & 1 & 2 & & & & 3 \\
\hline \multirow{2}{*}{ Capra/Ovis } & carpal 4 & 1 & & & & & 1 \\
\hline & pubis & 1 & & & & & 1 \\
\hline \multirow{2}{*}{ Odocoileus sp. } & pelvis & & 1 & & & & 1 \\
\hline & radius & & & & 1 & & 1 \\
\hline Odocoileus virginianus & ulna & & 1 & & & & 1 \\
\hline CF Equus & rib & & & 1 & & & 1 \\
\hline \multirow{7}{*}{ large mammal } & fragment & 1 & 1 & & & & 2 \\
\hline & longbone & & & & 8 & & 8 \\
\hline & lumbar vertebra & & 2 & & & & 2 \\
\hline & maxilla & 1 & & & & & 1 \\
\hline & rib & 3 & 1 & & & & 4 \\
\hline & thoracic vertebra & & 1 & & & & 1 \\
\hline & vertebra & & 3 & & & & 3 \\
\hline \multirow{3}{*}{ medium mammal } & longbone & & 1 & & 7 & & 8 \\
\hline & rib & 4 & 1 & & & & 5 \\
\hline & scapula & 2 & & & 1 & & 3 \\
\hline unidentified mammal & fragment & 2 & 6 & 1 & 2 & 1 & 12 \\
\hline unidentified & fragment & 1 & & & & & 1 \\
\hline & Tot & 21 & 35 & 2 & 23 & 2 & 83 \\
\hline
\end{tabular}


unidentified mammal fragments. Thirty (25\%) of the spiral breaks occur on large- and medium-sized mammal long bones. The remaining specimens are mammal vertebrae, ribs, scapulae, a bovid metacarpal, three bird long bones, and a turtle bone.

\section{Discussion}

The faunal assemblage from Mission San Juan is very fragmented with an average weight per bone of two grams. Only $6 \%$ of the specimens could be identified to at least the family taxonomic level. More than half (63\%) of the identified taxa came from Unit F. This unit was very disturbed down to $80 \mathrm{cmbd}$ by a pipe trench. This unit also contained the greatest number of bones showing butcher marks $(\mathrm{n}=55,66 \%)$. Unit $\mathrm{E}$ had the second highest percentage of identified taxa (15\%), with the remaining four units ranging from $3 \%$ in Unit A to $9 \%$ in Unit $D$. The trench present in Unit $\mathrm{F}$ also ran through Unit E. The fill in this trench may have come from a trash midden in another portion of the site.

The remaining units also showed varying amounts of disturbance, but the three units (A, B, D) with relatively undisturbed deposits in the lower levels were located some distance from each other. This makes any interpretation of species richness, meat utility, or butchering technique meaningless. The average weight of the bone fragments recovered from these unit is 1.4 grams. The small assemblage and bone size from these units is most likely due to their location next to the convento and Room 21 where a steplike feature was identified. These areas would likely not have been used to dispose of refuse. It is interesting to note that all of the cranial elements, including individual teeth, were recovered from these three units. Generally, the butchering sequence for large mammals involves the removal of the head and tail first (Clonts 1983). Then the animal is gutted and the carcass split down the center and the two halves processed. The slaughter and initial dressing of the animal would most likely have been done in an area away from living quarters or the convento, and the less desired items left at or near the slaughter site (Reitz and Wing 1999:236).

Four of the bones show severe weathering indicating they were exposed on the surface for some time. These were recovered from Level 2 of Unit D and Level 3 of Unit F. There were also 13 bones with carnivore chewing evident on them. These were recovered from Levels 2 and 3 in Unit B, Level 3 in Unit D, Level 4 in Unit E, and Levels 2 and 3 in Unit F. These bones were also on the surface or initially disposed of in areas accessible to scavenging animals. The weathering and carnivore chewing support the observations made during unit excavation that there is some disturbance in the upper levels of Units B and D and throughout Units $\mathrm{E}$ and $\mathrm{F}$.

Cattle and unidentified bovid bones make up 57\% $(\mathrm{n}=78)$ of the identified specimens; $77 \%$ by weight. Within the entire assemblage, cattle/bovid and large mammal make up $49 \%$ of the collection by weight. Of the identified taxa, deer/sheep/ goat, pig, and peccary make up $30 \%(n=42)$ of the identified specimens; $19 \%$ by weight. Of the entire assemblage, the medium-sized taxa listed above and unidentified medium mammal make up $27 \%$ of the collection by weight.

Bovid and unidentified large mammal bone fragments dominate the analyzed sample. This may indicate that mission inhabitants relied heavily on cattle, with wild mammals, such as deer, peccary and rabbits, as well as a variety of riverine species and birds contributing to the diet. The fragmented nature of the collection, especially the long bones, may indicate that the mission inhabitants processed bones for grease. These assumptions are in line with other faunal collections analyzed from Mission San Juan (Meissner 1993, 2000, 2001). The size of the sample and the disturbance evident in the units makes any further interpretations of the faunal data difficult.

The single human bone in the collection was recovered from a disturbed context (Unit E, Level 1) and does not represent an intact burial.

\section{Ceramics}

There was a total of 434 ceramic sherds recovered from the unit excavations (Table 5-9). The ceramic types range from Spanish Colonial to nineteenth-century wares. The majority of ceramics represented in the collection are English white earthenwares (47\%), followed by Native American Goliad wares (29\%), and Colonial wares (13\%). Other types present include stonewares (8\%), other English types (2\%), a Chinese porcelain fragment, one unglazed flower pot fragment, and one unknown ceramic type. Due to the broad time span for Native American Goliad wares, it is difficult to give a specific date for this ceramic type. Temporally, the earliest ceramics from the excavations are the Colonial wares and the Chinese porcelain that range in date from the eighteenth to the early nineteenth centuries. The types of 


\begin{tabular}{|c|c|c|c|c|c|c|c|c|c|c|c|c|c|c|c|c|c|c|c|c|c|}
\hline $\begin{array}{l}-\overrightarrow{0} \\
\frac{0}{2} \\
\underline{\underline{*}}\end{array}$ & \multicolumn{5}{|c|}{$T$} & \multicolumn{4}{|c|}{ (H) } & \multicolumn{3}{|c|}{$\bullet$} & \multicolumn{3}{|c|}{2} & \multicolumn{2}{|l|}{$\varpi$} & \multicolumn{2}{|r|}{$>$} & \multicolumn{2}{|l|}{ Unit } \\
\hline & a) un & + & $\omega$ & N & - & 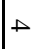 & $\omega$ & n & - & $\omega$ & N. & - & $\omega$ & N & $\omega$ & $N$ & - & $\omega$ t & N. & Level & \\
\hline- & & & & & & & & & & & & & & & & - & & & & Porcelain & Chinese Ceramic: Porcelain \\
\hline$N$ & & & - & & & & & & & & - & & & & & 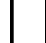 & & & & Red Burnished & Colonial Ceramic: Burnished \\
\hline$a$ & & - & $N$ & $n$ & & & & & & & & & & & & - & & & & Galera & \\
\hline- & & & & & & & & & & & & & & & & - & & & & Immature Glaze & Colonial Ceramic: Lead-glazed \\
\hline 기 & - & & $u$ & N & & $\omega$ & $\omega$ & ur & & - & $\omega, 1$ & $N$ & & - & & & & & - & Sandy Paste & \\
\hline- & & & & & & & & - & & & & & & & & & & & & Blue on White & \\
\hline$\omega$ & & & & - & - & & & & & & & & & & - & & & & & Guanajuato & \\
\hline$u$ & & & & & & & & & & u. & & & & & & & & & & Puebla Blue on White II & \\
\hline$\omega$ & & & & & & & & & & N & - & & & & & & & & & San Agustin & Comonar ceramice. 1m-giazed \\
\hline$\omega$ & & - & - & & & & - & & & & & & & & & & & & & San Elizario & \\
\hline a) & - & - & - & - & & & - & & & & & - & & & & & - & & & Undecorated & \\
\hline$\omega$ & & & & & & & & & & & & & & & & $\omega$ & & & & Undecorated & English Ceramic: Porcelain \\
\hline$N$ & & & & - & & & & & & & & & & - & & & & & & Copper Luster & English Ceramic: Copper Lusterware \\
\hline- & & & & & & & & & & & & & & & & - & & & & Lusterware & English Ceramic: Lusterware \\
\hline$N$ & & & & - & & - & & & & & & & & & & ( & & & & Albany & \\
\hline N & & & & & & & & & & & & & & & & No & & & & Albany/Bristol & \\
\hline- & & & & & & & & & & & & & & & & & & & & - Albany/Salt & AFolich Coromine Stanowar \\
\hline- & & & & - & & & & & & & & & & & & & & & & Alkaline Glaze & Engisn Ceramic: Stoneware \\
\hline- & & & & & & - & & & & & & & & & & & & & & Ash Glaze & \\
\hline- & & & & & & & & & & & & & & & & & - & & & Bristol & \\
\hline 기 & N & 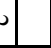 & $N$ & $\checkmark$ & & - & $N$ & - & - & & & & & & - & a & - & & $N$ & Annular & \\
\hline$N$ & & & & & & & & & & & & & & - & & - & & & 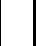 & Cut Sponge & \\
\hline 6 & - & & $N$ & N & & & & - & & & & & & - & n & & & & 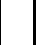 & Edgeware & \\
\hline$t$ & N & د & $a$ & 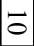 & & - & & ur & - & & $N$ & -1 & N & & 6 & + & & - & un & Hand-painted & \\
\hline$\infty$ & - & - & - & & & - & - & - & & & & & & - & & 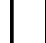 & & & - & Ironstone & \\
\hline- & & & & & & & & & & & & & & & & & & & - & Plain Colored Glaze & 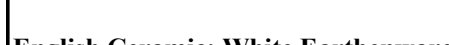 \\
\hline$N$ & & & & & & & & & & & & & & - & & - & & & 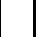 & Semi-English; Porcelain & \\
\hline$N$ & & & - & & & & & & & & & & & & & ( & & & - & Spatter ware & \\
\hline$\checkmark$ & & & & N & & & & - & & & & & & & & $\omega$ & & & 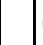 & - Sponge ware & \\
\hline 임 & - & - & & - & & n & - & - & - & & & & - & & $\triangle$ & $u$ & & & $N$ & - Transfer ware & \\
\hline$\infty$ & - & $-\omega$ & $\bar{N}$ & $\nexists$ & - & - & $a$ & ur & & & & $\omega$ & $\omega$. & + & un & 0 & $N$ & & $\infty$ & Undecorated & \\
\hline- & & & & & & & & & & & & & & & & & & - & & unknown & \\
\hline- & & & & & & & - & & & & & & & & & & & & & Yellowware & English Ceramic: Yellowware \\
\hline- & & & & & & & & & & & & & & - & & & & & & Unglazed Ceramic & Flower Pot \\
\hline $\bar{\sigma}$ & \begin{tabular}{l|l}
$N$ & $U$
\end{tabular} & 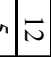 & $\omega$ & $\vec{D}$ & $D$ & $\omega$ & $\checkmark$ & $\infty$ & & $\omega$ & 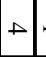 & - & - & $\omega$ & $\checkmark$ & - & $N$ & - & 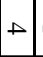 & Goliad & Native American Ceramic: Goliad \\
\hline- & & & & & & - & & & & & & & & & & & & & & Unknown Ceramic & Unknown Ceramic: Unglazed \\
\hline $\begin{array}{l}\vec{t} \\
⿱ 亠 䒑 \\
\oplus\end{array}$ & $\omega \mid \vec{A}$ & 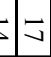 & ㄱ. & un & $a$ & ur & $\omega$ & $\mathbb{O}$ & $\omega$ & $=$ & $=$ & $\infty$. & $\checkmark$ & $\overrightarrow{+}$ & $-\infty$ & 9 & $\checkmark$ & $\omega:$ & $\sim$ & Total & \\
\hline
\end{tabular}


Colonial-period wares present include lead-glazed $(n=34)$, burnished $(\mathrm{n}=2)$, tin-glazed $(\mathrm{n}=21)$, and Chinese porcelain $(\mathrm{n}=1)$. The earliest Colonial ceramic type recovered from excavations was San Agustín tin-glazed that dates to the eighteenth century.

There is an abundance of English white earthenwares, both decorated and undecorated types, in the assemblage (Table 5-9). Edgeware $(n=9)$ is the earliest white earthenware represented in the collection, though it did not appear as frequently as hand-painted $(n=49)$ and annular wares $(n=27)$. Undecorated white earthenware $(n=78)$ was represented most frequently in the English ceramic types. Additional ceramics types present $(10 \%)$ that date to the late nineteenth and twentieth centuries are stoneware, porcelain, lusterwares, and yellowware.

\section{Analysis of Goliad Wares}

Goliad type refers to a Native American ware typically encountered in mission and other Spanish Colonial sites in central and south Texas. The prehispanic (prehistoric) predecessor to this type, which happens to appear physically identical, is known as Leon Plain. Goliad and Leon Plain wares have similar crushed bone tempering and also vessel shapes which consist of small bowls, jars and ollas (Ricklis 2000). There have been relatively few analyses of Goliad ceramics recovered from mission sites (Perttula 2002; Ricklis 1999, 2000; Ulrich et al. 2005).

The sample of Goliad ceramics recovered from the excavations at Mission San Juan Capistrano was analyzed as a single group without reference to unit and level provenience. This was done because of the degree of mixture of the deposits and because it was felt that the occupation dates of the mission (1731-1794/1823) offer reasonably tight temporal control. Also, it was hoped that the analysis of Goliad ceramics from this mission will provide a good comparative database to the already existing body of Goliad data that has been collected from other mission sites.

Recent analyses of Goliad wares include the sample from the 2005 excavations at Mission Espíritu Santo in Goliad County, Texas (Ulrich et al. 2005). This analysis identified three approaches to Goliad ceramic manufacture, primarily based on the differences in tempering agents. The analysis found that bone tempering was the predominant tempering ingredient in Goliad ceramics analyzed from Mission Espíritu Santo. In addition to bone, sand was another tempering agent found to be added during ceramic manufacture. Some Goliad wares may have been made using clay sources that contained small quantities of sand suggesting that the clays used in making some of these wares were sandy rather than being sand-tempered.

\section{Methods}

A sample of 77 Goliad ceramic sherds, including body, base and rim sherds, was used in this analysis. Rim sherds accounted for $26 \%, 4 \%$ consisted of base sherds, and the majority of the sherds were body pieces $(70 \%)$. Only sherds that were $20 \mathrm{~mm}$ or greater in maximum dimension were examined in the analysis. The analysis consisted of documenting the formal, technological and stylistic attributes for each sherd.

Formal attributes included the weight and wall thickness of each sherd, and vessel form. Maximum thickness of each sherd was determined buy using digital calipers. Vessel wall thickness may correlate with vessel function (e.g., cooking, serving, storage). Vessel forms were strictly determined from rim sherds. Other attributes recorded for rim sherds included the rim form, lip form (see Ricklis 2000; Ulrich et al. 2005), and orifice diameter. Rim forms were noted as either everted, inverted, straight, deep bowl or shallow bowl. Lip forms were recorded as pointed, round or flat. Orifice diameter was determined by placing the rim sherd on a concentric circle template composed of graduated $1-\mathrm{cm}$ rings.

Technological attributes refer to characteristics associated with the preparation of clays and the firing of the vessel. These attributes were determined by the type of aplastic inclusions, the relative quantity of the inclusions and the firing atmosphere of the vessel. Inclusions apparent in the temper of the ceramic may or may not have been purposely added (Rice 1987). Inclusions recorded for this analysis included crushed bone, sand, burned sandstone fragments and plant fiber. To identify the type of aplastic inclusions and density, each sherd was freshly broken and examined under 40X magnification. The density of the temper was recorded as being sparse, moderate or abundant. In some instances, when two or more types of inclusions were viewed, the density of each inclusion was noted.

The color of a vessel sherd is an indicator of the temperature of the firing and the atmosphere. The color of the interior, exterior and core of each sherd was examined. Brown, gray and black were recorded as reduced, while red, orange and buff were denoted as oxidized. A mixture of colors was 
recorded as zoned. Evidence of fireclouding, a darkened area on a vessel's surface as a result of uneven firing (Rice 1987) and/or contact with fire fuel or another vessel, was also noted.

Stylistic attributes refer to the surface treatments and decorations on the interiors and exteriors of sherds. The surface finish categories used for this sample included smooth, rough and polished or floated. Decoration categories included painted, asphaltum and smudged.

\section{Results}

The analysis attributes recorded are presented in Appendix A. Overall, the average thickness of the sherds is $6.42 \mathrm{~mm}$. When divided into sherd types, the average thickness of rims is $5.58 \mathrm{~mm}$, body sherds is $6.56 \mathrm{~mm}$, and base sherds is $9.46 \mathrm{~mm}$. There are 20 rim sherds in the analyzed sample. On average, the rim sherds from Mission San Juan Capistrano are thinner than sherds analyzed from Mission Espíritu Santo (Ricklis 2000; Ulrich et al. 2005), and thicker than rim sherds from Mission Rosario in Goliad County (Ricklis 2000). Using a template of rim forms and lip forms adopted from Ricklis (2000), vessel forms could be discerned. The attribute analysis concluded that 12 of the sherds are from deep bowls, six are from shallow bowls, and vessel form could not be determined for two sherds. The predominance of deep bowls is not surprising, given that they are versatile compared to shallower vessels. Within the Mission Espíritu Santo collection, Ulrich et al. (2005) found that deep and shallow bowls occurred in nearly identical numbers ( $\mathrm{n}=4$ and $\mathrm{n}=5$, respectively) and at least one sherd was derived from a bottle.

In the Goliad ceramic assemblage from Mission San Juan, the number of pointed $(n=10)$ and round $(n=9)$ lip forms was almost identical. Only one sherd appeared to be flat, which happened to be the only painted sherd. On average, there was not a great difference between the orifice diameter of shallow $(13 \mathrm{~mm})$ and deep bowls $(13.64 \mathrm{~mm})$.

The aplastic inclusions found in the ceramics included bone, plant fiber, sand and sandstone. Crushed bone was a tempering agent in all sherds and in $73 \%$ of the sherds it was the sole tempering ingredient (Figure 5-1). Twenty-two percent of the sherds contained both sandstone and bone. Only $4 \%(n=3)$ of the sherds contained a mixture of bone and sand, while only one percent $(\mathrm{n}=1)$ contained bone and plant fiber. Only sparse amounts of temper were present in $55 \%$ of the sherds, $11 \%$ contained abundant amounts of

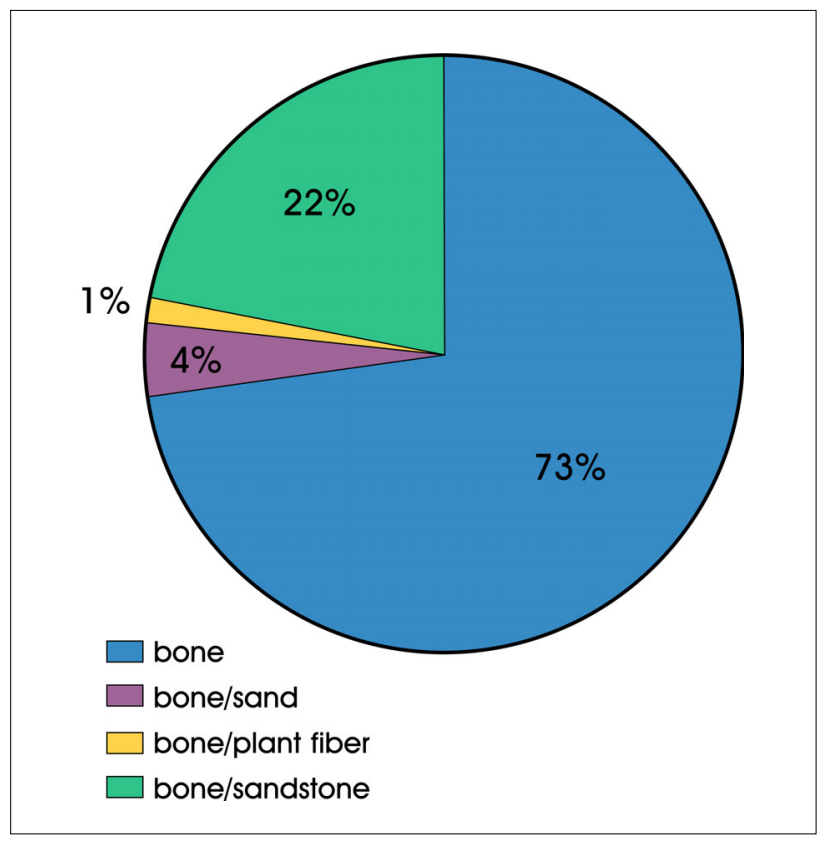

Figure 5-1. Percentages of temper types in Goliad ceramics.

temper, and 19\% contained moderate amounts of temper (Figure 5-2). In cases when bone was not the only tempering agent, but sand and/or sandstone were also included, sandstone was significantly more common than sand.

The firing atmosphere was determined by examining the color of the vessel sherd. It is assumed that the potters of Goliad wares used an open fire technique. Typically, open fires are used for low-fired, unglazed wares, and there is considerable variation in the temperature with this technique (Rice 1987:156). The colors of brown, gray or black signal reduced firing, which indicates insufficient oxygen. This atmosphere usually occurs in low-temperature or shortperiod firing. Lighter-colored sherds, such as red and orange, indicate oxidization, which is characterized by sufficient oxygen in the firing atmosphere. Examination of the sherd cores shows a higher percentage $(50 \%)$ were reduced, followed by oxidized $32 \%$, and a very small percentage were zoned (18\%; Figure 5-3a). A majority of the sherds analyzed had oxidized exterior surfaces $(66 \%$; Figure $5-3 b)$, while the remainder exhibited fireclouded (17\%), reduced (13\%), and zoned (4\%) exterior surfaces. The interiors of the sherds had a higher percentage of oxidized surfaces $(62 \%)$, followed by fireclouded (18\%) and reduced (17\%) surfaces (Figure 5-3c). Alteration of the vessel color can also occur during its use and the post-depositional environment (Rice 1987). 


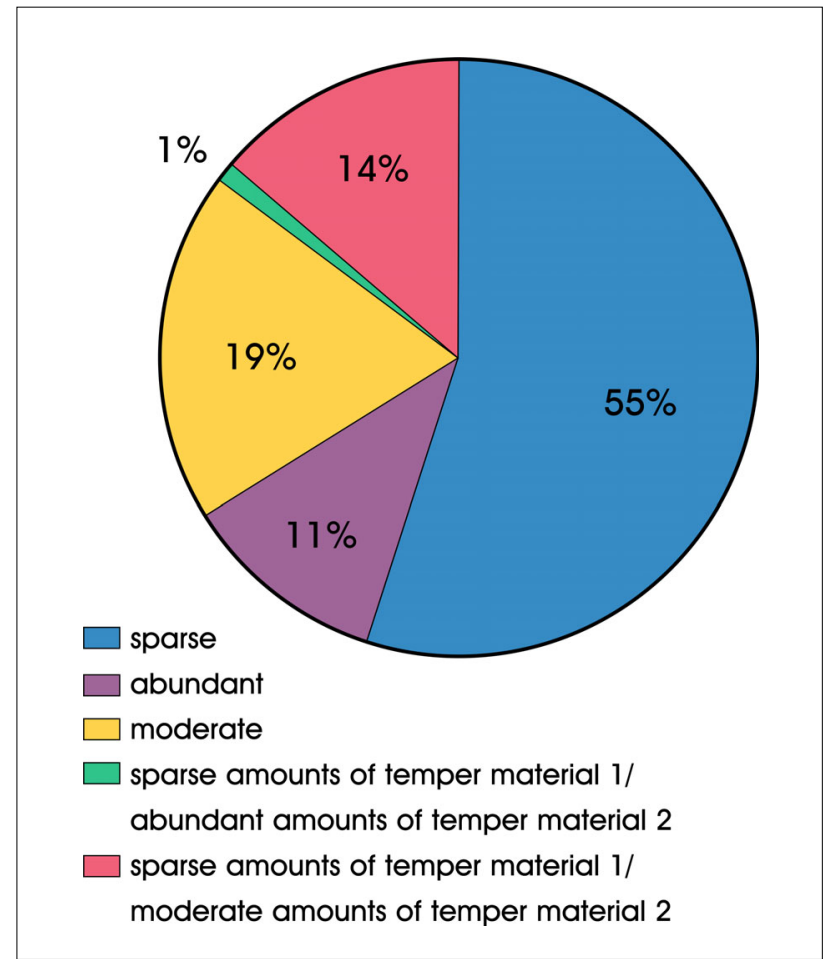

Figure 5-2. Percentages of temper material density in Goliad ceramics.

The finishing and decoration of Goliad sherds was noted for both the interior and exterior portions of the sherds (Figures 5-4 and 5-5). The majority of sherd interiors (89\%) and exteriors (84\%) were recorded as smooth (Figure 5-4). The terms floated and polished were used to indicate sherd surfaces that were smoothed intentionally (Ulrich et al. 2005). Sixteen percent of sherd exteriors exhibited signs of polishing or floating, while this finishing technique only appeared on $8 \%$ of sherd interiors. Minimal decoration was seen on the examined sherds (Figure 5-5). One rim sherd was painted on the interior with red paint. Eight percent of the sherds had evidence of smudging on the interior, which is a characteristic of open firing (Rice 1987:158). Asphaltum, which may have been applied for decoration or mending purposes, was evident on the exterior of $3 \%$ of the sample sherds. Goliad ceramics at Mission Espíritu Santo rarely had decorated surfaces compared to Mission Rosario ceramics (Ricklis 2000; Ulrich et al. 2005). Forty-three percent of the Goliad ceramics sample from Rosario displayed asphaltum decoration (Ricklis 2000:106).

\section{Summary and Conclusions}

The analysis of Goliad wares recovered from the 2005 excavations at Mission San Juan Capistrano found that a majority of the sherds were solely bone tempered. Identified vessel forms, inferred by rim forms, included deep and shallow bowls which are the most common forms identified at other mission sites (Ricklis 2000). Decoration was rare and only observed on a few sherds. On Goliad ceramics from Mission Espíritu Santo, decoration was not common either, as opposed to those from Mission Rosario which displayed asphaltum decoration (Ricklis 2005; Ulrich et al. 2005). Ricklis (2000:107) notes that the lack of asphaltum usage in particular missions may reflect a restrictive access to particular resources and other native groups. 


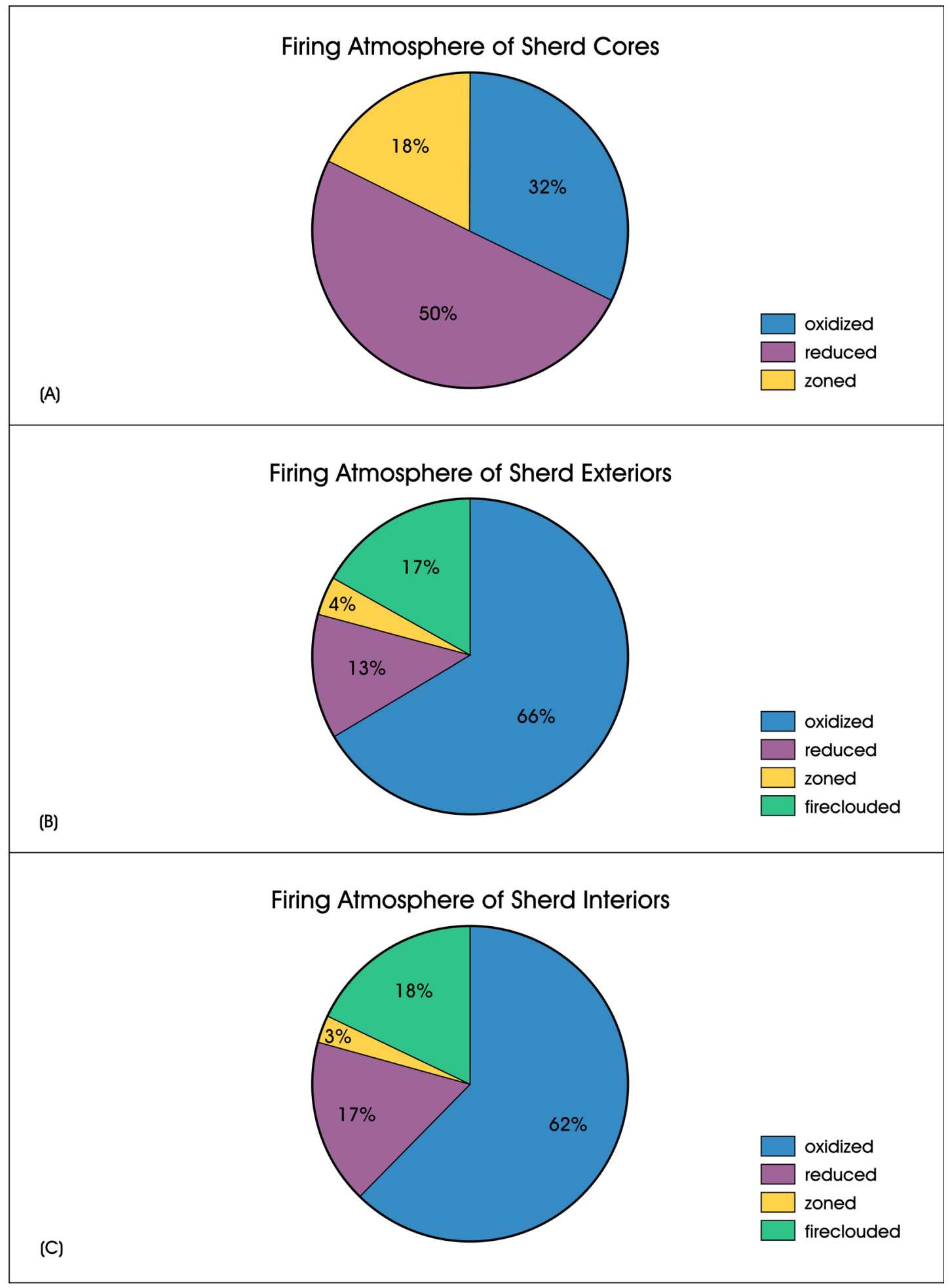

Figure 5-3. The firing atmosphere of Goliad sherd cores, exteriors and interiors (percentages). 
Finishing Techniques of Goliad Sherd Interiors

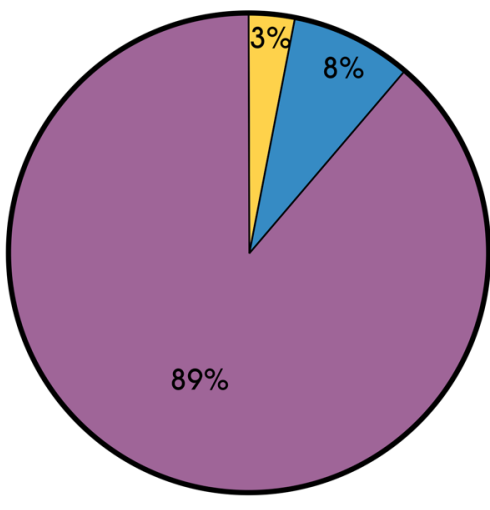
floated/polished smooth brushed

Finishing Techniques of Goliad Sherd Exteriors

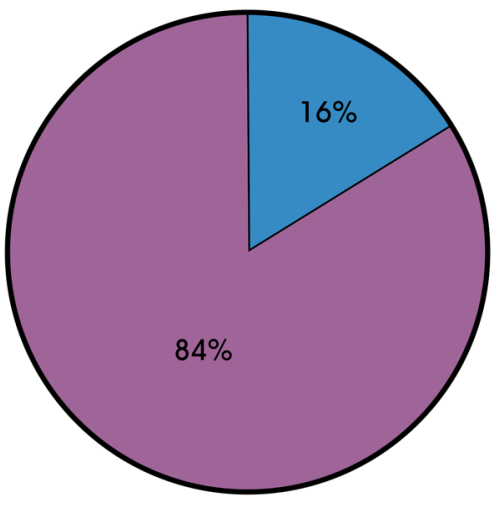
floated/polished smooth

Figure 5-4. Finishing techniques of Goliad sherd interior and exterior surfaces (percentages). 


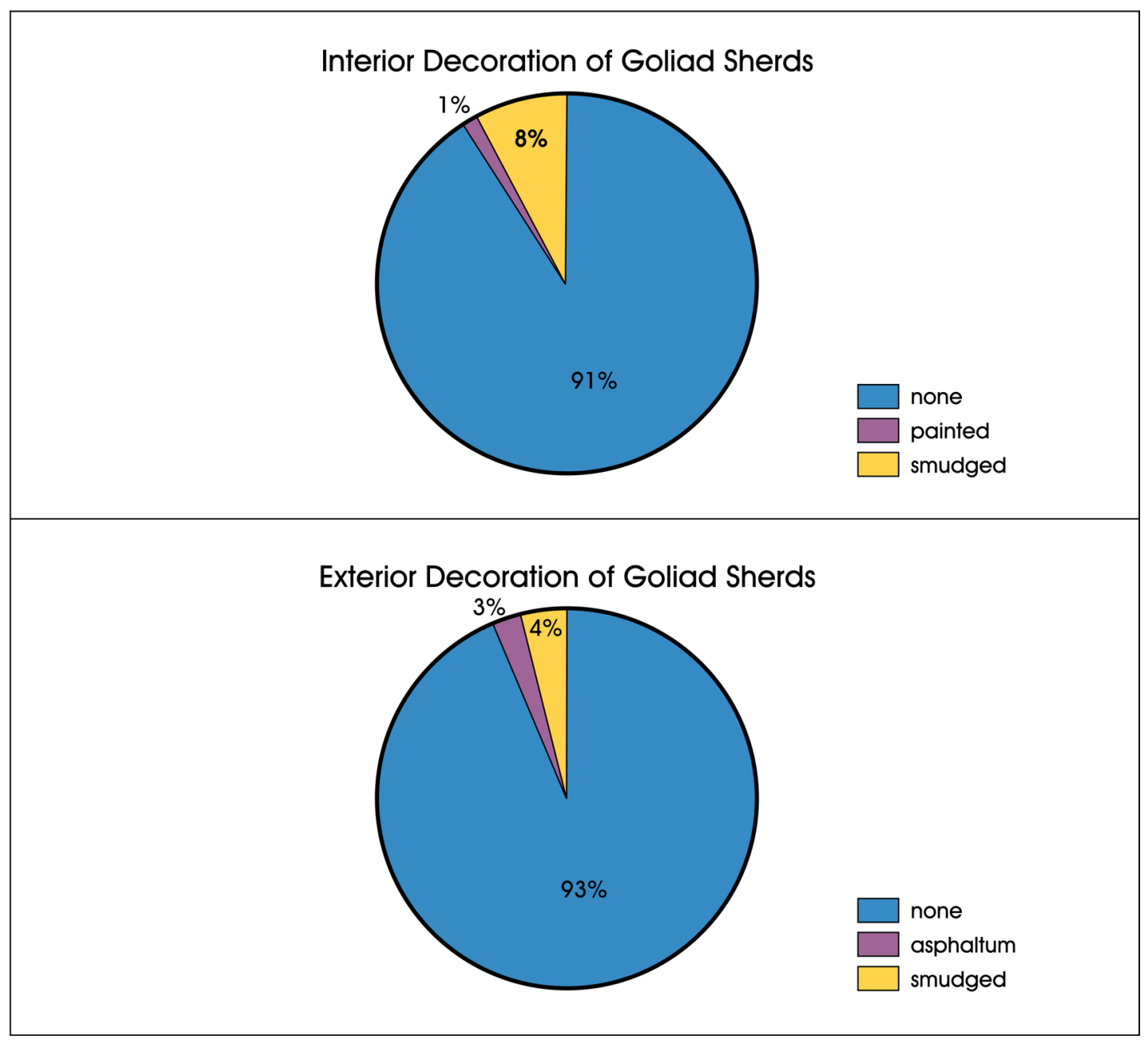

Figure 5-5. Decoration of Goliad sherd interior and exterior surfaces (percentages). 



\section{Chapter 6: Summary and Recommendations}

During January, 2005, CAR undertook exploratory archeological investigations at Mission San Juan Capistrano in advance of stabilization activities that will occur surrounding the convento. Six units were excavated over a five-day period. A half-day of probing was conducted in April, 2005, to more fully explore features uncovered during the January investigations. Each unit excavated produced an array of cultural material, giving insight to the extent of previous disturbance.

Three of the six units contained portions of pipe systems. Unit $\mathrm{C}$ contained two gray $\mathrm{PVC}$ pipes (one 1-inch and one 2.5 -inch) at approximately 32 to $43 \mathrm{~cm}$ below the surface. Unit E encountered a 10 -inch concrete pipe at approximately $68 \mathrm{~cm}$ below the surface. Unit $\mathrm{F}$ contained a concrete pipe that was encountered at $54 \mathrm{~cm}$ below the surface. While it is possible that intact soils lay beneath the PVC pipes located in Unit C, the artifact assemblage of Level 3 does not provide enough evidence to indicate a Colonial deposit. Units $\mathrm{E}$ and F can be considered highly disturbed due to the previous installations of the pipes and the depth at which they were found. In addition, the butresses were constructed as recently as 1968 (Ford, Powell \& Carson 2003). Any stabilization activity along the path of the pipes will not impact intact deposits.

The single human bone (metacarpal) recovered during excavations came from the highly disturbed first level of Unit $E$ and does not represent an intact burial. Upon being informed of the identification of human remains within the assemblage, NPS consulted with Native American Graves Protection Act (NAGPRA) and legal experts and it was determined that this was not a NAGRPA incident because NPS does not have "significant legal claim" to the land. Therefore, after consultation with the Archdiocese of San Antonio, the incidental finds procedures that were developed by NPS and the Archdiocese in 2001 were put in place.

Though they do not contain pipe trenches, the remaining three units appear to contain disturbances as well. Sediments found in the first levels of Units A, B, and D indicate previous activities along the convento wall. The artifact assemblage of Unit A consisted of mid- to lateeighteenth-century items that may indicate later construction activities north of the convento. Unit B produced artifacts that represent the mid to late nineteenth century, and the presence of the stone step poses an interesting question. It is possible that the stones were placed to provide a step for a doorway along the east wall of the convento, although there is no evidence of a door located above the step. The placement of the step was done with care, though its purpose is not known at this time. Unit $D$ revealed portions of the original sandstone wall foundation, though the matrix was a mix of concrete and sandstone construction debris. Cultural material was disturbed within the first two levels, but Level 3 produced the most promising possibility of undisturbed sediments.

The impermeable barrier, consisting of a plastic polymer, will be installed at a depth of six inches (approximately 15 $\mathrm{cm}$ ) in the immediate vicinity of the walls and it will slope to 18 inches (approximately $45 \mathrm{~cm}$ ) below surface by the time it extends out to eight feet from the bases of the walls. The excavations conducted by CAR clearly document that in Units A, B, C, E and F, no intact deposits are found within the upper $60 \mathrm{~cm}$ of matrix. Relatively intact deposits appear to be present in the lower portion $(50-60 \mathrm{~cm}$ below surface) of Level 3 in Unit D, adjacent Rooms 21 and 22. However, in this area, the plastic polymer fabric will be installed at a depth of approximately $15 \mathrm{~cm}$ below surface, therefore, no disturbances are expected to the intact Colonial deposits found in the deepest excavation level and below. The CAR excavations did not establish whether the general pattern of disturbed deposits noted against the walls of the convento is also characteristic of the matrix eight feet from the bases of the walls. However, the installation of the impermeable fabric will be monitored by Susan Snow, NPS archeologist, and if any intact deposits are noted during the process, work will stop and an appropriate course of action will be determined in consultation with the Texas Historical Commission.

Finally, the excavation of Units $\mathrm{E}$ and $\mathrm{F}$ exposed the subsurface portion of one of the buttresses of the convento. The condition of the building material is good and requires no improvements. In addition, and more importantly, it was determined that the buttresses serve no load-bearing functions and are strictly decorative. Therefore, at this time, no additional work will be carried out that will impact any of the buttresses surrounding the convento. 
In summary, the units excavated during this project indicate that the areas to be impacted by the stabilization already exhibit disturbance. Undisturbed Colonial-aged deposits were identified between $50 \mathrm{~cm}$ and $60 \mathrm{~cm}$ below surface in Unit $\mathrm{D}$ adjacent Rooms 21 and 22, but subsurface impacts are not going to reach to this depth in this area. Unit $\mathrm{D}$ also produced an interesting step-like feature, although no information is available as to its purpose or where it may have led. The planned stabilization activities will be monitored by the NPS archeologist, and if undisturbed deposits are encountered, work will stop until an appropriate plan of action will be determined in consultation with the Texas Historical Commission. 


\section{References Cited}

Balkwill, D. M., and S. L. Cumbaa

1992 A Guide to the Identification of Postcranial Bones of Bos taurus and Bison bison. Canadian Museum of Nature, Ottawa.

Binford, L. R.

1981 Bones: Ancient Men and Modern Myths. Academic Press, San Diego.

Boessneck, J.

1970 Osteological Differences Between Sheep (Ovis aries Linné) and Goats (Capra hircus Linné). In Science in Archaeology, edited by D. Brothwell and E. Higgs, pp. 331-358. Praeger, New York.

Brown, C. L., and C. E. Gustafson

1979 A Key to Postcranial Skeletal Remains of Cattle/Bison, Elk, and Horse. Reports of Investigations, No. 57. Laboratory of Anthropology, Washington State University, Pullman.

Cargill, D. A.

1996 Stable Isotope Analysis at Mission San Juan Capistrano, San Antonio, Texas. Unpublished Master's thesis, Department of Anthropology, The University of Texas at San Antonio. On file, Center for Archaeological Research, The University of Texas at San Antonio.

Cargill, D. A., and R. C. Robinson

2000 Archaeological Testing and Monitoring of a Service Drive at Mission San Juan Capistrano, San Antonio, Texas. Archaeological Survey Report, No. 296. Center for Archaeological Research, The University of Texas at San Antonio.

Clonts, J. B.

1983 Some Long Overdue Thoughts on Faunal Analysis. In Forgotten Places and Things: Archaeological Perspectives on American History, edited by A. E. Ward, pp. 349-354. Center for Anthropological Studies, Albuquerque.

Cox, I. W., J. F. Durst, D. D. Edmonson, B. A. Meissner, and S. T. Tomka

2001 Archaeological Investigations at Four San Antonio Missions: Mission Trails Underground Conversion Project. Archaeological Survey Report, No. 297. Center For Archaeological Research, The University of Texas at San Antonio.

Escobedo, J.

1985 The Post Colonial House: An Excavation Report. On file, Center for Archaeological Research, The University of Texas at San Antonio.

Ford, Powell \& Carson, Architects \& Planners, Inc.

2003 Condition Assessment and Preservation Analysis. Mission San Juan Capistrano 3. Ford, Powell \& Carson, Architects \& Planners, Inc., San Antonio, Texas. On file, San Antonio Missions National Historical Park. 
Fox, A. A.

1993 Archaeological Testing and Monitoring in Connection with a Drainage Project at Mission San Juan Capistrano, San Antonio, Bexar County, Texas. Archaeological Survey Report, No. 217. Center for Archaeological Research, The University of Texas at San Antonio.

1999 Monitoring of Core Drilling and Testing at Mission San Juan Capistrano and San Francisco de la Espada, San Antonio, Bexar County, Texas. Ford, Powell \& Carson, Inc. and the Archdiocese of San Antonio.

Francis, J. R.

1999 Non-Indian Burials at the Spanish Colonial Missions: San Juan Capistrano, San Antonio, Texas. Paper presented at the Society for Historical Archaeology $32^{\text {nd }}$ Conference on Historical and Underwater Archaeology, Salt Lake City, Utah.

Gilbert, B. M.

1990 Mammalian Osteology. Missouri Archaeological Society, Columbia.

Gross, K. J.

1998 Archaeological Testing and Monitoring for a Proposed Drainage Channel at Mission San Juan Capistrano, San Antonio, Texas. Archaeological Survey Report, No. 283. Center for Archaeological Research, The University of Texas at San Antonio.

Habig, M. A.

1968 The Alamo Chain of Missions. A History of San Antonio's Five Old Missions. Franciscan Herald Press, Chicago.

Hildebrand, M.

1955 Skeletal Differences Between Deer, Sheep, and Goats. California Fish and Game 41:327-346.

Hillson, S.

1986 Teeth. Cambridge University Press, Cambridge.

Ivey, J. E., A.A. Fox

1999 Archaeological Investigations at Mission Concepción and Mission Parkway. Archaeological Survey Report, No. 114. Center for Archaeological Research, The University of Texas at San Antonio.

Ivey, J. E., M. B. Thurber, and S. Escobedo

1990 Of Various Magnificence, The Architectural History of the San Antonio Missions in the Colonial Period and the Nineteenth Century. National Park Service Professional Papers No. 11. Santa Fe. Draft on file, Center for Archaeological Research, The University of Texas at San Antonio.

Meissner, B. A.

1993 Appendix II: Faunal Remains Recovered during San Juan Drainage Project. In Archaeological Testing and Monitoring in Connection with a Drainage Project at Mission San Juan Capistrano, San Antonio, Texas, by A. A. Fox, pp. 27-35. Archaeological Survey Report, No. 217. Center for Archaeological Research, The University of Texas at San Antonio.

2000 Vertebrate Faunal Remains. In Archaeological Testing and Monitoring of a Service Drive at Mission San Juan Capistrano, San Antonio, Texas, by D. A. Cargill and R. C. Robinson, p. 11. Archaeological Survey Report, No. 296. Center for Archaeological Research, The University of Texas at San Antonio. 
2001 Vertebrate Faunal Remains. In Archaeological Investigations at Four San Antonio Missions: Mission Trails Underground Conversion Project, edited by C. L. Tennis, pp. 35-47. Archaeological Survey Report, No. 297. Center for Archaeological Research, The University of Texas at San Antonio.

Olsen, S. J.

1964 Mammal Remains from Archaeological Sites Part I; Southeastern and Southwestern United States. Peabody Museum, Cambridge.

1968 Fish, Amphibian, and Reptile Remains from Archaeological Sites Part I: Southeastern and Southwestern United States. Peabody Museum, Cambridge.

1969 Post-Cranial Skeletal Characters of Bison and Bos. Kraus Reprint Co., New York.

Perttula, T. K.

2002 Native Ceramics. In Archaeological Excavations at the Last Spanish Colonial Mission Established on the Texas Frontier-Nuestra Señora del Refugio (41RF1), Refugio County, Texas, edited by C. L. Tennis, pp. 233-260. Archaeological Survey Report, No. 315, Center for Archaeological Research, The University of Texas at San Antonio, and Archeological Studies Program, Report No. 39, Environmental Affairs Division, Texas Department of Transportation, Austin.

Procter, B.

1965 San Juan Capistrano. In Six Missions of Texas, D. H. Winfrey, historical coordinator. Texian Press, Waco.

Reitz, E. J., E. S. Wing

1999 Zooarchaeology. Cambridge Manuals in Archaeology, Cambridge University Press, United Kingdom.

Rice, P. M.

1987 Pottery Analysis: A Sourcebook. The University of Chicago Press, Chicago.

Ricklis, R. A.

1999 The Spanish Colonial Missions of Espiritu Santo (41GD1) and Nuestra Senora del Rosario (41GD2), Goliad, Texas: Exploring Patterns of Ethnicity, Interaction, and Acculturation. Bulletin of the Texas Archeological Society 70:133-168.

2000 Archeological Investigations at the Spanish Colonial Missions of Espiritu Santo (41GD1) and Nuestra Senora Del Rosario (41GD2), Goliad County, Texas. Coastal Archeological Studies, Inc. Corpus Christi, Texas.

Schuetz, M. K.

1968 The History and Archeology of Mission San Juan Capistrano, San Antonio, Texas, Volume I. Report 10. State Building Commission Archeological Program, Austin.

1969 The History and Archeology of Mission San Juan Capistrano, San Antonio, Texas, Volume II. Report 11. State Building Commission Archeological Program, Austin.

1974 The Dating of the Chapel at Mission San Juan Capistrano, San Antonio, Texas. Special Report No. 12. Office of the State Archeologist, Texas Historical Commission, Austin.

1980 The Indians of the San Antonio Missions 1718-1821. Ph.D. dissertation, The University of Texas at Austin.

Scurlock, D.

1976 Archeological and Architectural Tests at Mission San Juan Capistrano Church. Special Report No. 21. Office of the State Archeologist, Texas Historical Commission, Austin. 
Sobolik, K. D., and D. G. Steele

1996 A Turtle Atlas to Facilitate Archaeological Identifications. Fenske Companies, Rapid City, South Dakota.

Taylor, F. B., R. B. Hailey, and D. L. Richmond

1966 Soil Survey of Bexar County, Texas. United States Department of Agriculture, Soil Conservation Service, in Cooperation with the Texas Agricultural Experiment Station, Series 1962(12).

Turner, D. D.

1988 Excavations at San Juan Capistrano, 41BX5, Bexar County, Texas. Archaeological Survey Report, No. 171. Center for Archaeological Research, The University of Texas at San Antonio.

Ulrich, K. M., A. L. Figueroa, J. L. Thompson, A. A. Fox, J. M. Hunziker, S. A. Tomka, and C. M. Muñoz

2005 Archeological Investigations at Mission Espíritu Santo (41GD1), Goliad County, Texas. Archaeological Report, No. 356. Center for Archaeological Research, The University of Texas at San Antonio.

Villalobos, C.

2003 A Study of Gunflints from Spanish Colonial Sites. Unpublished Masters Thesis, The University of Texas at San Antonio. On file, Center for Archaeological Research, The University of Texas at San Antonio.

Zapata, J.

1997 Alamodome and Abroad: A Composite Inquiry on Toy Marbles. In Archaeology at the Alamodome: Investigations of a San Antonio Neighborhood in Transition. Volume III: Artifact and Special Studies, edited by A. A. Fox, M. Renner, and R. J. Hard, pp. 100-118. Archaeological Survey Report, No. 238. Center for Archaeological Research, The University of Texas at San Antonio.

Zapata, J. E., M. J. Brown, and J. J. Durst

2000 Archaeological Excavation of the Priest Quarters, Mission San Francisco de la Espada, 41BX4, San Antonio, Texas. Archaeological Survey Report, No. 295. Center for Archaeological Research, The University of Texas at San Antonio. 
Appendix A

Recorded Analysis Attributes for Goliad Ceramics from Mission San Juan Capistrano 


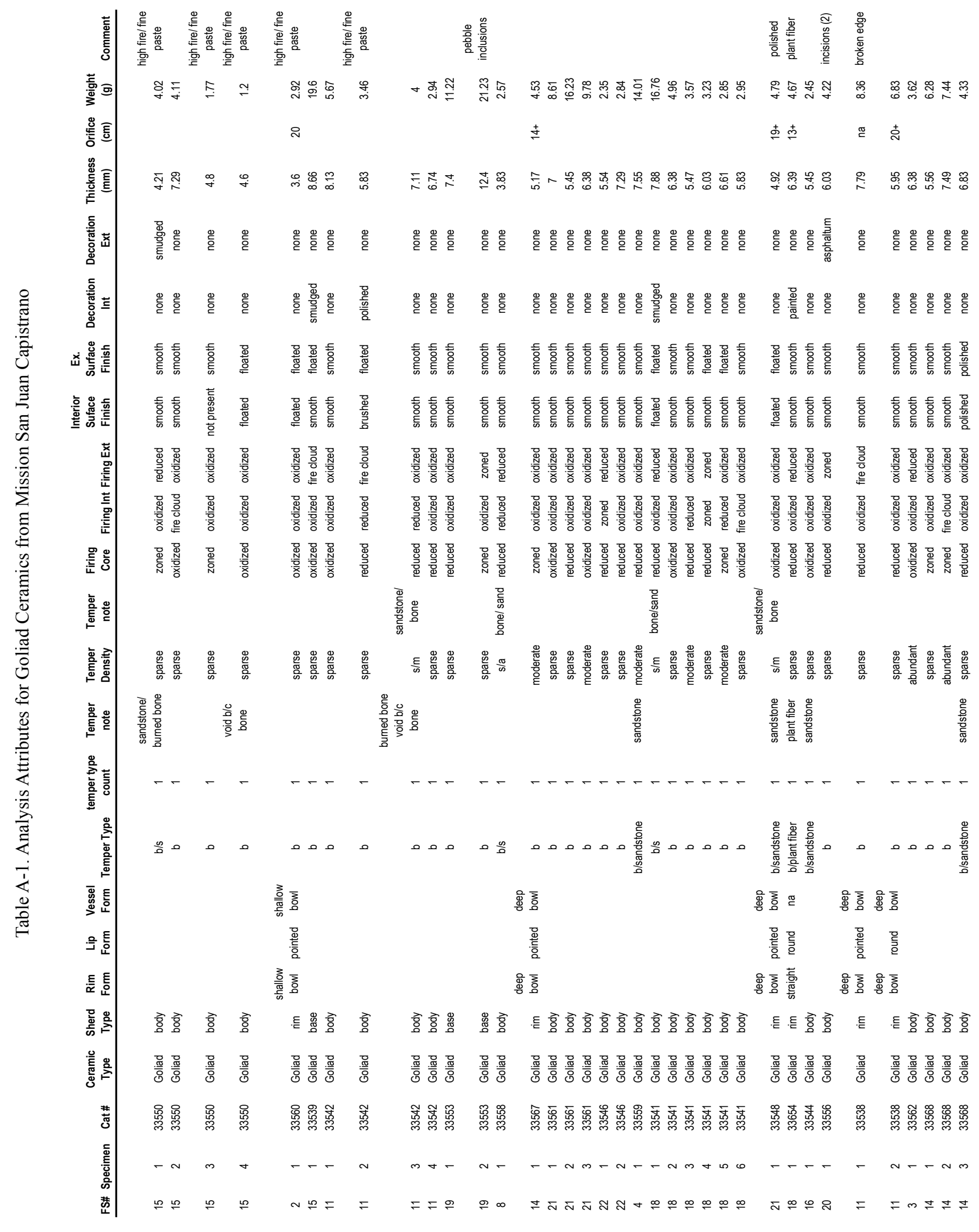




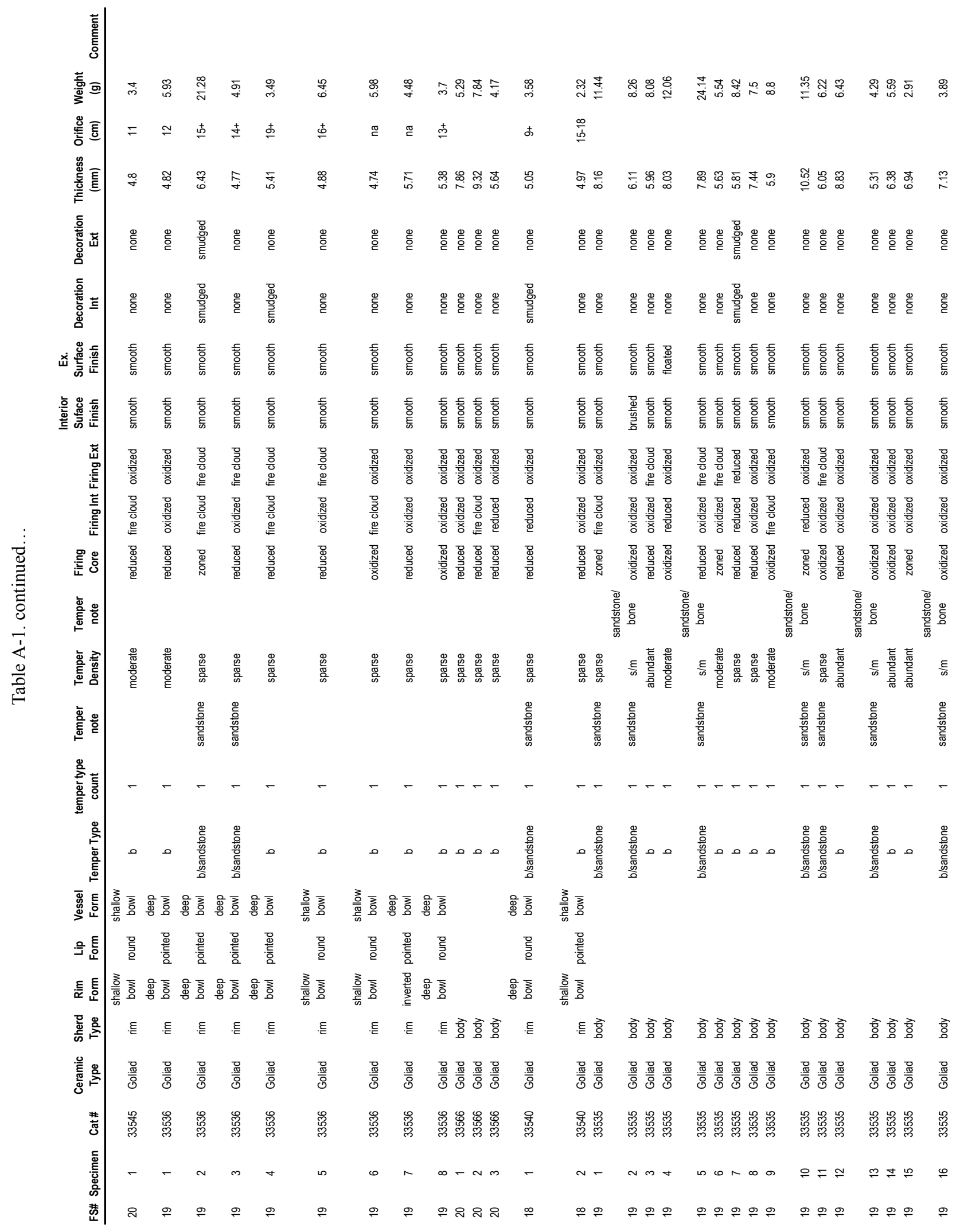




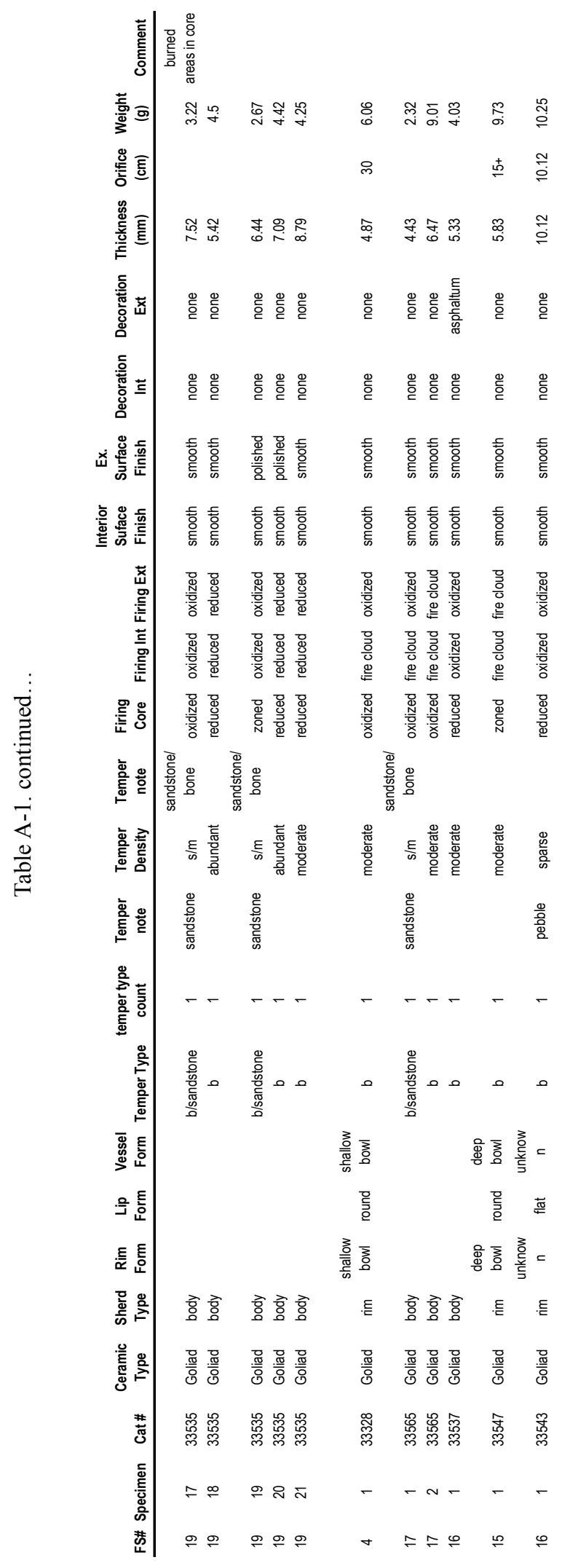

